\title{
A Review of Performance-Enhancing Innovative Modifications in Biodiesel Engines
}

\author{
T. M. Yunus Khan ${ }^{1,2}$ D
}

1 Research Center for Advanced Materials Science (RCAMS), King Khalid University, PO Box 9004, Abha 61413, Saudi Arabia; yunus.tatagar@gmail.com

2 Department of Mechanical Engineering, College of Engineering, King Khalid University, Abha 61421, Saudi Arabia

Received: 1 August 2020; Accepted: 24 August 2020; Published: 26 August 2020

\begin{abstract}
The ever-increasing demand for transport is sustained by internal combustion (IC) engines. The demand for transport energy is large and continuously increasing across the globe. Though there are few alternative options emerging that may eliminate the IC engine, they are in a developing stage, meaning the burden of transportation has to be borne by IC engines until at least the near future. Hence, IC engines continue to be the prime mechanism to sustain transportation in general. However, the scarcity of fossil fuels and its rising prices have forced nations to look for alternate fuels. Biodiesel has been emerged as the replacement of diesel as fuel for diesel engines. The use of biodiesel in the existing diesel engine is not that efficient when it is compared with diesel run engine. Therefore, the biodiesel engine must be suitably improved in its design and developments pertaining to the intake manifold, fuel injection system, combustion chamber and exhaust manifold to get the maximum power output, improved brake thermal efficiency with reduced fuel consumption and exhaust emissions that are compatible with international standards. This paper reviews the efforts put by different researchers in modifying the engine components and systems to develop a diesel engine run on biodiesel for better performance, progressive combustion and improved emissions.
\end{abstract}

Keywords: biodiesel; modifications; intake manifold; fuel injection; exhaust manifold; efficient engines

\section{Introduction}

The internal combustion (IC) engine is the prime mover as far as transportation is concerned in our society. The IC engine converts the chemical energy contained by the fuel into heat energy and subsequently heat into work. Engine modifications and developments have been taking place for better efficiency and lower fuel consumption. Fuels also have a major impact on engine design, modifications and developments.

The diesel engine, which is one of the prime movers for transportation, has undergone many modifications since its invention for better performance, low fuel consumption besides lower emissions due to stringent emissions norms of the legislature. Diesel has a higher energy density compared to gasoline. Therefore, diesel engines in automobiles provide higher mileage, making it an obvious choice for heavy-duty transportation and equipment. Diesel engines employ compression-ignition for igniting the fuel. Thus, the diesel engine design is simpler than the gasoline engine, which needs a spark plug in order to ignite the fuel and air mixture. However, fossil fuels are depleting rapidly, and it has even been projected that they may only last for few decades more [1-3]. Therefore, the search for new alternate fuels for diesel engine has gained momentum in recent decades [4-7].

Though biodiesel has emerged as an alternate to diesel for compression ignition engines, the formation of oxides of nitrogen (NOx), lesser brake thermal efficiency, and increased fuel consumption are still the major concerns in the unmodified diesel engine [8-10]. Hence, the focus 
is to make the diesel engine more efficient by modifying the engine components or systems for an engine operated on biodiesel-diesel blends. The fluid flow in intake manifold, fuel injection system, combustion, heat transfer, etc., are relevant to the internal combustion engine for better performance, efficiency, emissions and fuel requirements [11]. Hence, the focus is to make the diesel engine more efficient by modifying the engine components or systems for engine operated on biodiesel-diesel blends. The fluid flow in intake manifold, fuel injection system, combustion, heat transfer, etc., are relevant to the internal combustion engine for better performance, efficiency, emissions and fuel requirements [12-17]. The impact of variables of the IC engine and other parameters on biodiesel engine performance and emissions were reviewed. It was concluded that the optimized engine variables and parameters would give maximum possible efficiency with minimum emissions [18,19]. Combustion chamber (CC) geometry is an important engine design parameter. The progressive and efficient combustion in any internal combustion engine depends on the type of CC geometry. The effect of different combustion geometries on the performance and emissions has been reviewed [20]. However, to the best of authors' knowledge, there is no paper that reviews the modifications that have taken place in the biodiesel engines. This paper reviews the research carried out by modifying the different engine components, namely intake manifold, fuel injection and exhaust manifold using biodiesel-diesel blends as fuel.

\section{Intake Manifold Modifications}

The air or air-fuel mixture (charge) flow in the intake manifold is a complex phenomenon in diesel and petrol engines, respectively. The effectiveness of the air induction intern depends on intake system which is known with the help of volumetric efficiency. This section reviews the various methods of modifications done in the intake manifold of the biodiesel engine.

\subsection{Hydrogen Addition}

Rocha et al. [21] installed a small L-shaped tube in the center of the intake pipe. They anticipated that the fluctuations due to the rapid functioning of both valves improve the mixing of hydrogen and air. Furthermore, hydrogen addition increased the energy content of the fuel (biodiesel + hydrogen). The results showed a reduction in specific fuel consumption besides a decrease in emissions such as carbon dioxide $\left(\mathrm{CO}_{2}\right)$, carbon mono-oxide $(\mathrm{CO})$ and hydrocarbons $(\mathrm{HC})$. However, there was an increase in nitrogen oxide (NOx) due to a higher cylinder temperature [21]. An experimental and numerical study on combustion and performance was conducted with $20 \%$ rapeseed biodiesel and $80 \%$ diesel with different fractions of hydrogen contents. Both studies concluded with a decrease in CO, smoke and the total unburned hydrocarbon (TUHC) emissions and an increase in Nox by adding fractions of hydrogen contents with air in the intake manifold. There was no significant change in ignition delay by enriching hydrogen with the diesel and biodiesel blend [22]. Tests conducted on the diesel engine by using diesel, neat grapeseed oil and grapeseed biodiesel for different shares of hydrogen additions showed an increase in brake thermal efficiency (BTE) from 3\% to $4 \%$ for a maximum share of hydrogen energy. There was a decrease in emissions such as $\mathrm{HC}, \mathrm{CO}$ and $\mathrm{CO}_{2}$ but the trend of Nox was found to be increased [23]. A comparison study of enriching pure hydrogen and hydroxyl (HHO) with sunflower biodiesel was carried out by Mustafa et al. [24]. They found the engine better in terms of performance when run on biodiesel by enriching $\mathrm{HHO}$ with the intake air. However, the engine run on biodiesel with enriching pure hydrogen was found to be better as far as emissions are concerned [24]. The thermal efficiency of biodiesel engine run on tamanu methyl ester is less besides high smoke compared to diesel engine. The trend obtained regarding the performance and emissions was same as discussed above. In addition to hydrogen induction in the intake manifold, the biodiesel was blended with ethanol, which resulted in an increase in BTE and a reduction in Nox, $\mathrm{CO}$ and smoke [25]. The experiments conducted with different volumetric flow rates of biodiesel and diesel mixtures in a test engine with hydroxyl gas addition showed an improved engine performance with lesser emissions except Nox. The brake power was improved by $8.3 \%, 7.1 \%$ of brake torque and $10 \%$ of brake specific fuel consumption [26]. According to Radu and Nicolae [27], there were 
some contradictory results on emissions when $20 \%$ biodiesel-diesel blend was used. They conducted combustion and emissions tests on conventional tractor by using B20 (rapeseed biodiesel) enriched with hydrogen. There was no significant change in engine combustion characteristics. The addition of hydrogen lowered emissions such as smoke and CO but with a significantly higher concentration of Nox [27]. Rapeseed biodiesel-butanol blend also produced a higher concentration of Nox with reduced concentrations of $\mathrm{CO}$ and particulate matters. However, it was reported that exhaust gas recycle (EGR) could be used to control the excessive formation of Nox [28]. Hydrogen was inducted at varying flow rates of $4-12 \mathrm{~L} / \mathrm{m}$ with honge biodiesel. The results obtained showed the similar trends of improved thermal efficiency with reduced $\mathrm{CO}, \mathrm{HC}$, smoke and a higher concentration of Nox [29].

It could be summarized that the formation of Nox is a major issue when hydrogen is added in the intake manifold of the diesel engine when operated on blends of biodiesel and diesel. There are few researchers who have tried to reduce the formation of Nox. Higher in-cylinder temperature and availability of oxygen are responsible for the formation of Nox in compression ignition engines. Hence, water in biodiesel emulsions has been tested for increased thermal efficiency and a reduction in the formation of Nox [30-35]. There was a reduction of 32\% in formation of Nox, a $7.4 \%$ reduction in smoke, and a $2.3 \%$ and $1 \%$ reduction in $\mathrm{CO}$ and hydrocarbon (HC) were reported when water emulsified pongamia biodiesel was used in a 4-S diesel engine [36]. There are many issues in using hydrogen as a singular fuel in diesel engines. To overcome these issues a mixture of hydrogen and carbon monoxide was injected in the intake manifold in biodiesel engine. This resulted in a decrease in biodiesel consumption with a minimal increase in the formation of Nox [37]. The formation of Nox along with other emissions can also be reduced by methods such as intake manifold water injection, combined effect of steam injection and ferric chloride, etc., in diesel engines [38-43]. Intake manifold water injection was employed for rapeseed biodiesel-based four stroke, compression ignition and turbo-charged engines. It was reported that injecting the water at $3 \mathrm{~kg} / \mathrm{h}$ reduced the formation of Nox by $50 \%$. However, there was no significant change in performance and combustion parameters of the engines [44]. A similar trend of performance and emissions was reported recently for the diesel-canola biodiesel blend with steam injection in the intake manifold [45].

\subsection{Alcohol Fumigation Modes}

Diesel engine particulate matter, $\mathrm{CO}, \mathrm{HC}$ and Nox are serious threats to human health and the environment [46]. To control these emissions, more and more tough norms are being implemented around the globe through legislations. Hence, reducing these emissions from any engine is of prime importance and of course one of the most significant challenges for any researcher who is working on engine design and development. The after-treatment processes and in-cylinder combustion techniques are being developed and improved by modifying fuels to mitigate the tailpipe Nox emission and formation in the cylinder, respectively. Some literature is available on the review of the alcohol fumigation mainly methanol and ethanol $[47,48]$. In this section, the recent literature on alcohol, gaseous fumigation modes used in biodiesel engines has been reviewed. Fumigation of ethanol in the intake manifold of a CI engine run on B7 fuel gave an increase in both thermal and exergy efficiencies. A substantial reduction of $69 \%$ in smoke index and also a reduction in the formation of $\mathrm{CO}$ and $\mathrm{CO}_{2}$ were reported. Nevertheless, an increase in $\mathrm{HC}$ and specific fuel consumption were noted. There was not any mention about Nox; however, there was a reduction in exhaust gas temperature [49]. Edvin Geo et al. [50] studied the effects of ethanol fumigation on the performance, combustion as well as emissions of diesel engines run on crude rubber seed oil and its methyl esters. The researchers found that an increase in the quantity of ethanol injection increased the BTE of the engine operated on rubber seed oil as well as its biodiesel besides reduced smoke emissions with higher concentrations of Nox, $\mathrm{CO}$ and HC. The combustion parameters such as in-cylinder pressure and rate of peak pressure rise also increased. However, the combustion duration was less, which led to an increase in heat release rate [50]. Higher viscosity and low volatility are the two main problems associated with crude oils when they are used in diesel engines directly instead of diesel though they have suitable energy 
contents. To overcome these issues, engine with low heat rejection (LHR) concept, carbureting the alcohols in the intake manifold were tested by using jatropha crude oil as the fuel. The performance of the engine jatropha crude oil was found to be better for engines with an LHR combustion chamber and a maximum induction of alcohol than the conventional engine with appropriate injection parameters. Furthermore, it was reported that ethanol injection was better for conventional engines and methanol injection was suitable for engines with an LHR combustion chamber. However, an increase in the levels of oxides of nitrogen Nox was reported [51].

It should be noted that the prime factor for Nox formation is a higher temperature inside the engine cylinder. Thus, it can be said that any effort that reduces the engine temperature should also be able to curb the Nox formation. Such possible efforts are noted in the work of engines run on pure diesel. In a 4-S diesel engine, bioethanol was fumigated in the intake manifold at different flow rates during suction stroke. It was found that, by fumigating the bioethanol at a rate of $0.48 \mathrm{~kg} / \mathrm{h}$, the brake specific nitric oxide (BSNO) and smoke were found to be lower by $24.2 \%$ and $25 \%$, respectively, than that of pure diesel at full load operating conditions. The researchers concluded that the reduction in BSNO was due to high latent heat of vaporization of bioethanol, reduction of air induction and slow start of heat release rate [52]. A similar trend was obtained by using bioethanol E85 when used in three cylinder direct injection diesel engine [53].

Goldsworthy [54] fumigated ethanol-water mixture in heavy duty common rail marine diesel engine. The vaporized ethanol-water mixture was injected into intake manifold at different flow rates. The test set up for manifold injection is shown in Figure 1.

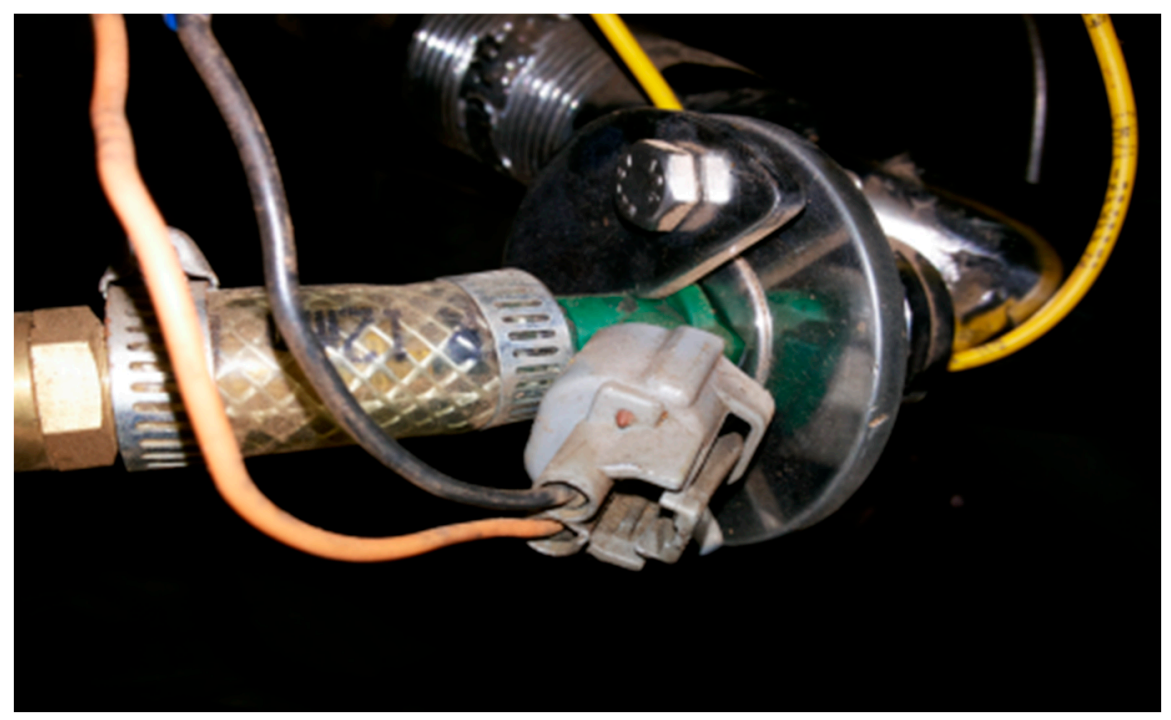

Figure 1. Installation of an ethanol injector in an intake manifold.

It was reported that Nox reduced with an increase in the flow rate of the ethanol-water mixture. The reduction of Nox may be attributed to the presence of water contents in the combustion chamber, which reduces the combustion temperature inside the cylinder [54]. Notwithstanding the complication of dual fuel supply systems and proper phasing of combustion, the operating conditions need to be fully understood. Furthermore, the material used for port ethanol injection systems is mainly carbon steel which is liable to stress corrosion cracking (SCC) [55]. SCC does not provide any form of prior warning to failure and it has far more adverse effects [56].

It was found from the vast literature available on diesel and biodiesel that the trend of performance and emissions of these two types of fuels go hand in hand. Thus, it can be predicted that any parameter that reduces the Nox in the diesel engine would also reduce the Nox in the biodiesel engine. On this basis, the Nox reduction in biodiesel engine should be tried as per the modifications adopted in diesel engines [52-54]. 


\subsection{Gasoline Fumigation}

In gasoline engines, air and gasoline are premixed outside the engine cylinder during intake stroke of the cycle. Combustion of the charge is followed by the spark initiated by spark plug. If this gasoline is fumigated in diesel engines, then it has been reported in the literature that the engine performance and emissions would be improved $[22,57,58]$. This concept of gasoline fumigation has been tested in diesel engine run on B20 biodiesel two different ratios. Using B20 biodiesel with gasoline fumigation increased the formation of Nox slightly, but a considerable reduction in unburned hydrocarbon (UHC), $\mathrm{CO}$, and smoke capacity exhaust gas temperature were noted [59]. The energy and exergy analysis was carried B20 biodiesel and diesel. It was found that the efficiencies of both energy and exergy were almost equal at higher operating loads. However, destructed exergy with biodiesel and the fumigation of gasoline were greater in biodiesel and fumigation [60].

\subsection{Incorporating Guide Vanes}

The airflow behavior in both intake manifold and cylinder are essential factors in forming an ideal air-fuel mixture. As the engine speed increases, flow rate increases with a corresponding increase in swirl and turbulence. This increases the rate of fuel evaporation, mixing of fuel vapor and air and combustion that leads to improved combustion efficiency $[19,61,62]$. Swirl is used in many modern CC designs to enhance the burning process and achieve greater combustion stability [63]. The nature of air flow in the intake manifold of an engine is an extremely complex phenomenon that makes it extremely difficult to be determined experimentally. This factor has motivated many researchers to rely on simulation as against experimentation [64-70].

Swirl can be created by bringing the intake flow into the cylinder with an initial angular momentum. Swirl can be developed by engine designs with a bowl in piston combustion chambers, setting up the rotational motion of air by modifying the intake system, etc.

The effects of incorporating guide vanes at different angles in the intake manifold was studied for a diesel engine generator run on higher viscous biodiesel. The optimum vane angle was found to be 350 by computer simulation. The other vane parameters, such as vane height, vane number and vane length, were kept constant. Though the optimum vane angle was 350 , the researchers fabricated and tested the generator for different vane angles ranging from $25^{\circ}$ to $45^{\circ}$ experimentally. Figure 2 shows the photographs of the different guide vanes.

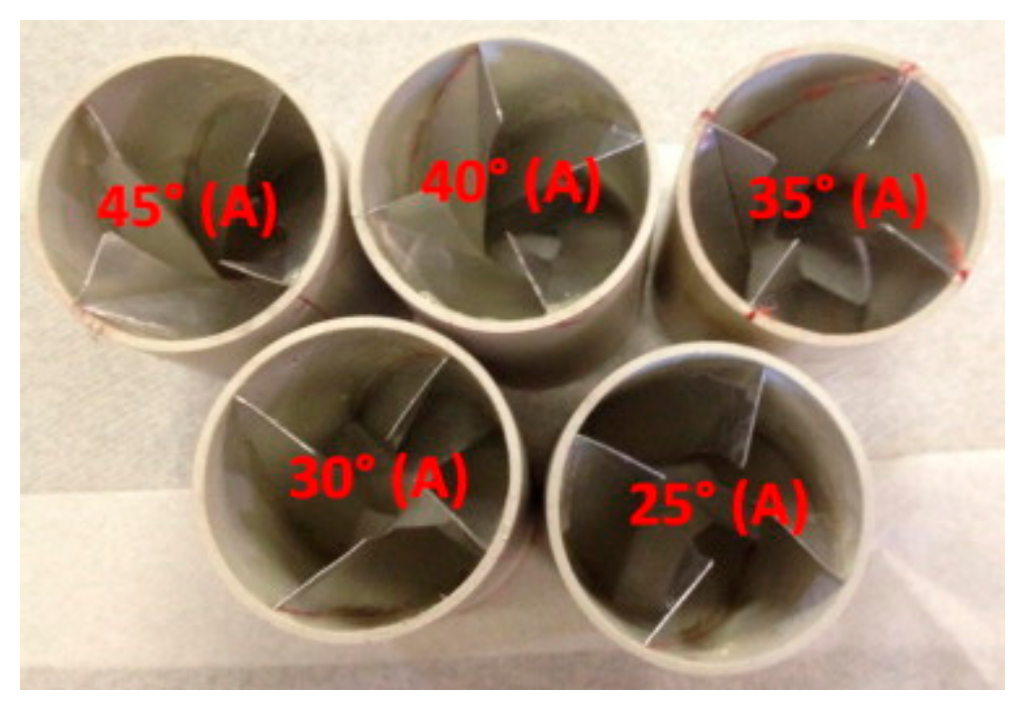

Figure 2. Images of the guide vanes.

They concluded that a vane angle of $35^{\circ}$ gave the best possible efficiency, reduced brake specific fuel consumption (BSFC) and reduced emissions [64]. The same researchers further studied the 
performance by optimizing the vane height by simulation using SolidWorks and ANSYS-CFX. The vane height of 0.70 times the radius of intake runner obtained by simulation results was fabricated and tested on a compression ignition diesel engine generator run on biodiesel. They found that a reduction in BSFC, CO and HC improved thermal efficiency [65]. It is a known fact that biodiesel possesses higher viscosity than diesel, which is responsible for lower combustion efficiency. This issue was mitigated by installing guide vane swirl and tumble device (GVSTD) in the air intake system to aid the effective breaking of biodiesel particles and mixing it with the molecules of air. It is a promising way to have a better mixing of air and biodiesel mixture [66]. Similar type of trend with respect to performance was obtained for different optimizations and configuration [67-69]. Therefore, it can be stated that, by optimizing the guide vanes height, number and length, the combustion efficiency could be improved beside improved performance and lower emissions for biodiesel engines.

\subsection{Intake Manifold Water Injection (IMWI)}

The formation of Nox is the result of a high-temperature combustion process. It affects the respiratory system. The high latent heat and specific heat of water that is being injected in the intake manifold may reduce the in cylinder temperature and hence may reduce the quantity of Nox being formed in the diesel engine [71]. However, some researchers attributed to the dilution effect affected the engine performance and emissions [72]. Intake manifold water injection was claimed to be an effective way to contain the in cylinder combustion temperature and formation of Nox. The CFD simulation tests conducted on direct injection diesel engine and turbocharged engine produced remarkably less amounts of both Nox as well as soot [38]. The same trend of reduction in Nox was observed when diesel engine was run with $100 \%$ biodiesel prepared from rapeseed oil at two different engine loading conditions. Water was injected at different mass flow rate of $0 \mathrm{~kg} / \mathrm{h}, 1.8 \mathrm{~kg} / \mathrm{h}, 3 \mathrm{~kg} / \mathrm{h}$. The formation of Nox was found to decrease at various engine operating conditions with an increase in the speed of the engine. Higher engine speed increases the volumetric efficiency and gas flow motion, which leads to the rapid mixing of air with fuel, resulting in shorter ignition delay. Therefore, the time available for the reaction between the oxygen and free nitrogen is significantly reduced. Shorter ignition delay minimizes the formation of Nox. Furthermore, by Nox was reduced with an increase in water flow rate proportionately [44].

\subsection{Thermal Barrier Coating}

The engine cylinder, combustion chamber and many other components of internal combustion engine are made up of metals. Metals are low-temperature materials and good thermal conductors, which is why heat losses from the engine cylinder are greater. The heat losses from the engine reduces the power developed and hence the performance [73-76]. Thermal barrier coatings minimize the heat losses from the engine and they also increase durability of the engine components due to their excellent thermal insulation properties [77-80]. The recent study carried out by using Moringa oleifera biodiesel blended with an additive in direct injection water cooled diesel engine showed improved brake thermal efficiency and reduced brake specific fuel consumption in a coated engine. The emissions CO, HC and Nox were in fact less in the biodiesel-antioxidant blend than diesel fuel [81].

The piston and both valves of the single cylinder compression engine were modified by coating with the layers of different ceramic $\mathrm{B}^{2040 \mathrm{TiO}_{2}}$ materials. The performance and emissions tests were carried out by using biodiesel from waste cooking oil at same engine operating conditions for both coated engine and without coated engine. The results show that the performance was better, and parameters such as brake specific fuel consumption reduced considerably beside lower emissions except Nox. Increased Nox were the result of increased combustion temperature [82]. The top surface of the piston and valves were coated with two layers. A total of $100 \mu \mathrm{m}$ of Nickel Chromium Aluminum (NiCrAl) was used as the first layer, known as a lining layer, by the plasma spray coating method. Furthermore, this layer was coated with a $400 \mu \mathrm{m}$ layer consisting of a mixture of $88 \%$ zircon oxide $\left(\mathrm{ZrO}_{2}\right), 4 \% \mathrm{MgO}$ (magnesium oxide) and $8 \%$ Aluminum oxide $\left(\mathrm{Al}_{2} \mathrm{O}_{3}\right)$. Some improvements in the 
performance and combustion parameters of the engine when tested for different biodiesel fuel blends were found [83].

\subsection{Pre-Heating CI Biodiesel Engines}

The engine performance and emissions of any engine intern depends upon the quality of the fuel being used in the engine [84-86]. Biodiesel as a fuel for a diesel engine has major problems, such as higher viscosity, low heating value and low volatility [87-93]. The pre-heating of biodiesel or crude oils decreases their viscosity and makes them suitable for diesel engines [94,95]. The pre-heating and exhaust gas recycle (EGR) tests were conducted by using jatropha biodiesel-diesel blend. The optimum blend was B40. In the beginning, the fuel was heated to $102{ }^{\circ} \mathrm{C}$ in the intake manifold, which reduced the kinematic viscosity and density of the biodiesel by $49 \%$ and $4.3 \%$, respectively. There was a significant decrease in BSFC and an increase in thermal efficiency. The formation of emissions such as unburned hydrocarbon and carbon monoxide were reduced, but oxides of nitrogen increased by $17.5 \%$. This increased in Nox was reduced by $68.8 \%$ by inclusion of EGR [96]. The heat carried by the exhaust gases was utilized to pre-heat the biodiesel made by palm oil. The pre-heated palm oil/diesel blends tested in a diesel engine at a constant speed of $1500 \mathrm{rpm}$ at different loading conditions are shown in Figure 3. The blend of $20 \%$ palm oil and diesel was found to the most suitable blend for different performance and emissions parameters. Furthermore, the pre-heated palm oil with the addition of an antioxidant gave better performance with reduced emission levels than diesel [97].

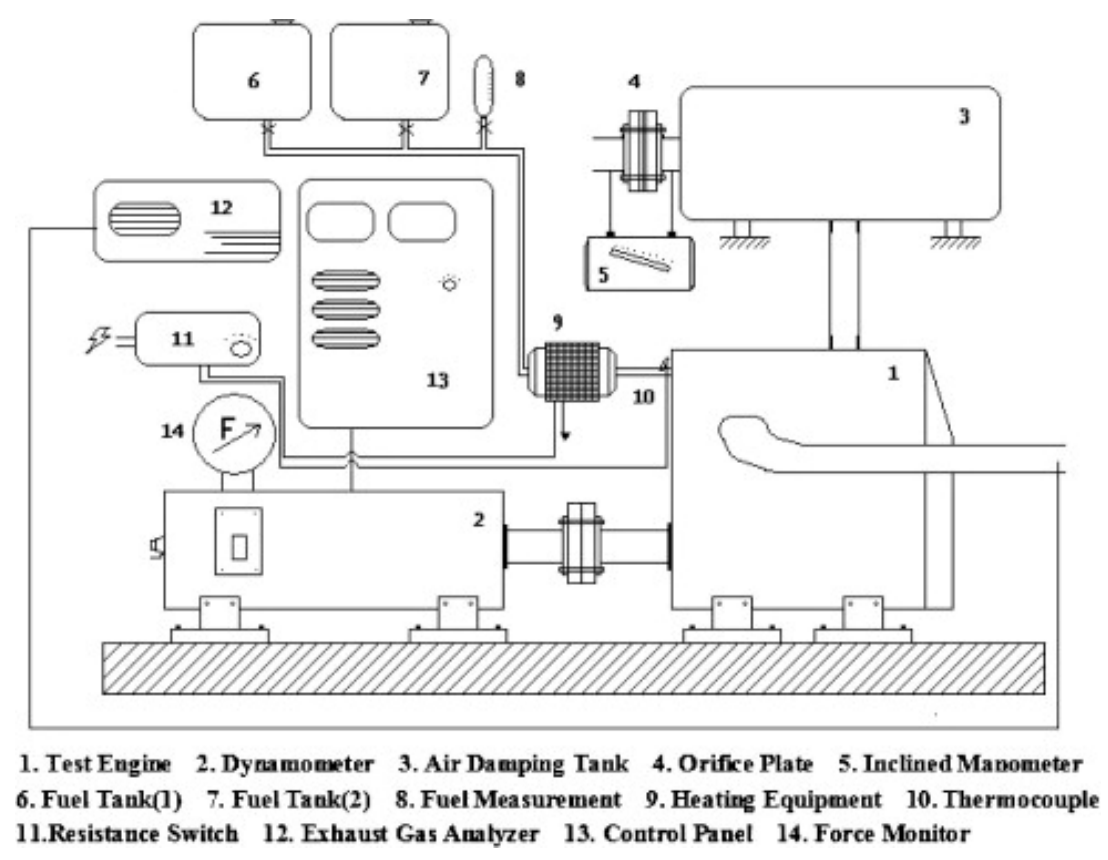

Figure 3. Schematic diagram of diesel engine set-up.

Nadir [98] studied the effect of air pre-heating on the operation of a diesel engine when operated on the blends of biodiesel and methanol with different concentrations. The pre-heating of the intake or lowering the methanol concentration in the blend of biodiesel and methanol reduced $\mathrm{CO}$ and $\mathrm{HC}$ but not Nox [98]. It can be observed that Nox emissions are more when either air or biodiesel fuel is pre-heated, but its formation may be controlled by installing EGR. Figure 4 indicates the summary of intake manifold modifications. 


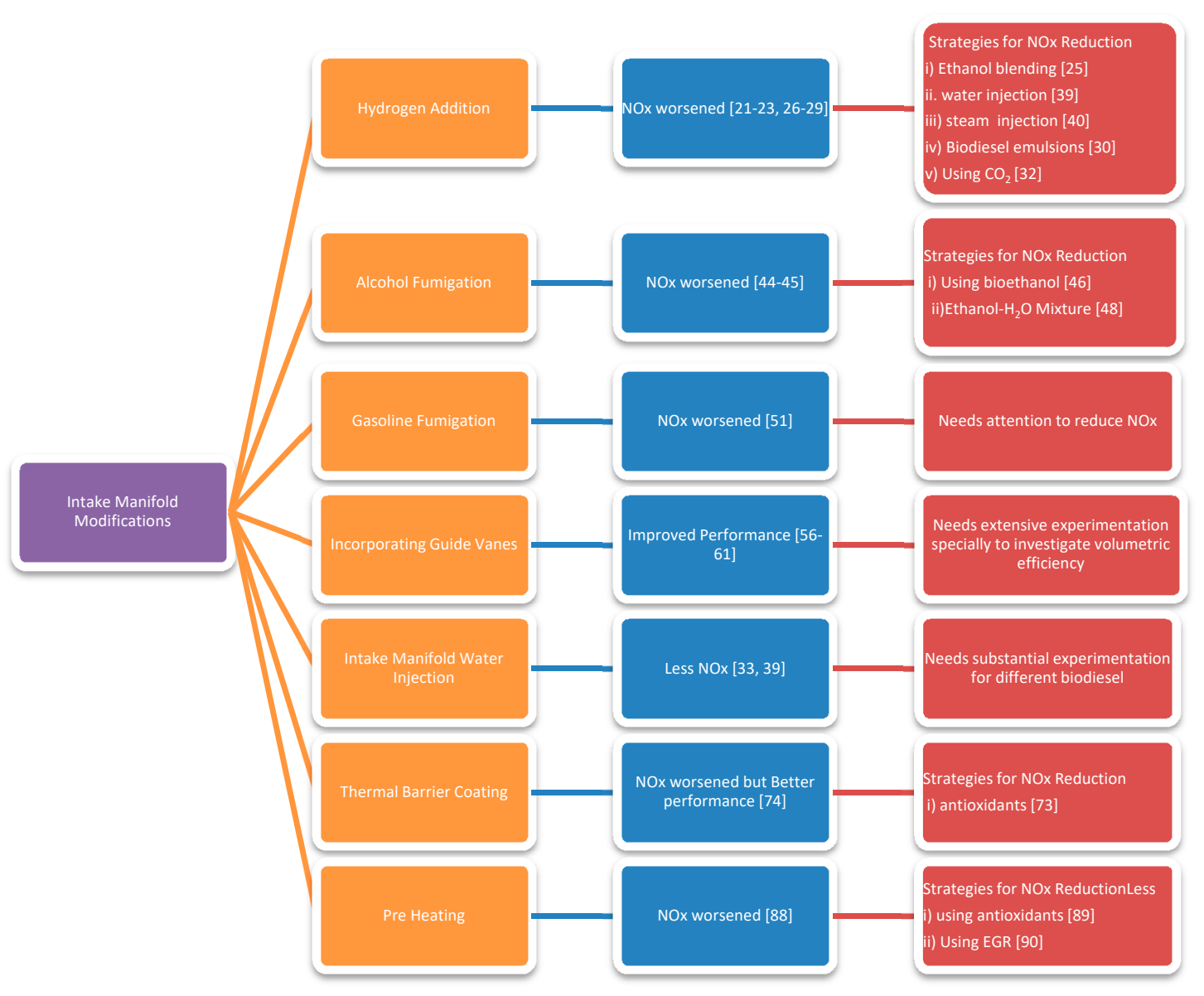

Figure 4. Schematic diagram of intake manifold modifications.

\section{Fuel Injection}

Fuel injection affects the combustion and emissions significantly [99]. The main components of a diesel fuel injection system are an injection pump, delivery pipe and fuel injector nozzles. The requirements of a fuel injection system are [100-105]:

- Fuel must be injected at desired timing of combustion;

- The injected fuel must have correct quantity as required;

- The spray pattern should ensure rapid mixing of air with the fuel;

- The beginning and end of the fuel injection should be sharp.

The fuel-injection rate, fuel nozzle design (including number of holes), and fuel-injection pressure all affect the characteristics of the diesel fuel spray and its mixing with air in the combustion chamber [100,106-108].

\subsection{Nozzle Geometry}

Nozzle geometry is one of the parameters on which the quality of atomization of the fuel in the diesel engine depends [109-112]. In fact, the effectiveness of the combustion and performance of a compression ignition diesel engine depends on the nozzle geometry $[113,114]$. Mahua biodiesel blended with diesel was run in CI diesel engine for performance, combustion and emissions. The fuel injector nozzle had three holes with different sizes of $\varnothing=0.20 \mathrm{~mm}$ (modified), $\varnothing=0.28 \mathrm{~mm}$ (base), and $\varnothing=0.31 \mathrm{~mm}$ (modified), as shown in Figure 5 . 

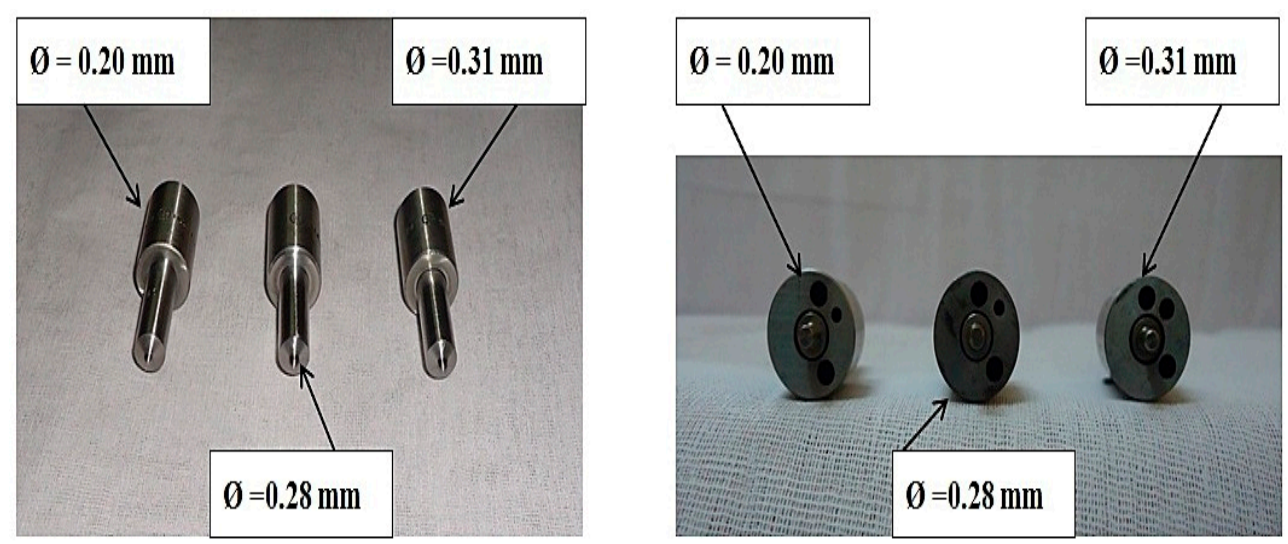

Figure 5. Nozzles of different sizes.

The results show that the performance, combustion and emissions parameters were better for a smaller nozzle diameter of $0.20 \mathrm{~mm}$ because the small nozzle diameter makes the mixing of biodiesel-diesel blend with air effective, which makes the combustion more efficient. In this research, the combination of B20 biodiesel and diesel blend with smaller nozzle diameter resulted in improved performance, combustion and emissions characteristics. However, an increase in the formation of Nox was a matter of concern [115]. Mahantesh et al. [116] recently studied the combined effects of nozzle geometry and combustion chamber shapes. They conducted the performance and emissions tests on a four-stroke diesel engine with different blends of pongamia pinnata biodiesel and diesel. They compared the results of unmodified engine with three-hole nozzle geometry and HCC (Hemispherical Combustion Chamber) with that of different modified combustion chamber shapes such as CCC (Cylindrical Combustion Chamber), SCC (Shallow-depth Combustion Chamber) and TCC (Torroidal Combustion Chamber) with five-hole nozzle geometry. The operating conditions of an engine, such as injection pressure, injection timing and compression ratio, were held constant. The different combinations gave different results with some advantages and some drawbacks. However, they concluded that emissions were less in all the modified engines with reduced brake thermal efficiency [116]. Effect of nozzle holes and combustion chamber geometry was studied by using honge methyl esters (HOME) and producer gas combination in a diesel engine. The study was carried out in two stages. In the first phase number of nozzle, hole diameter and injection pressure were optimized to $4,0.25 \mathrm{~mm}$ and 230 bar, respectively. These optimized nozzle geometries were used to conduct the performance tests by using two different types of combustion chambers, such as hemispherical combustion chamber (HCC) and re-entrant combustion chamber (RCC). On an average with optimized nozzle geometry with a 230 bar injection pressure, the combination of honge and producer gas with RCC gave increased brake thermal efficiency, reduced emissions such as smoke, HC, and CO but increased Nox level [117]. Increased injector hole number decreased the BSFC, smoke opacity, CO, $\mathrm{HC}$ and increased Nox and $\mathrm{CO}_{2}$, especially for the higher concentrated biodiesel-diesel blends (B50 and B100) [118]. The increase in the formation of Nox was also noticed in multi-injection strategies in biodiesel engines though; there was a decrease in the formation of soot, $\mathrm{HC}$ and $\mathrm{CO}$. However, there was an increase in indicated mean effective pressure [119]. A detailed study on effects of injection parameters, including the nozzle geometry and swirl was studied by Tumbal et al. [120] on honge oil methyl ester. They concluded that running the diesel engine with an increased number of holes with a smaller hole size in the fuel injector will improve the performance of the engine significantly [120].

The literature on nozzle geometry and combustion chamber reveals that either performance is better or Nox formation is less. To obtain both the improved performance and reduced emissions in general and Nox in particular, cerium oxide nanoparticle (CON), a nano fuel additive, was added to Calophyllum Inophyllum Methyl Ester (CIME). The tests were conducted with different nozzle geometries having holes of three (base, $\varnothing=0.280 \mathrm{~mm}$ ), four (modified, $\varnothing=0.220 \mathrm{~mm}$ ) and five (modified $\varnothing=0.240 \mathrm{~mm}$ ) holes. It was found that emissions such as hydrocarbon and Nox reduced considerably 
with improved brake thermal efficiency (BTE) and reduced brake specific fuel consumption with $\mathrm{NH} 5$ (five holes and $\varnothing=0.240 \mathrm{~mm}$ ). In these tests, $\mathrm{CON}$ acted both as an oxidation and reducing catalyst, which provided the oxygen for the oxidation of $\mathrm{CO}$ and absorbed oxygen to reduce the formation of Nox [121]. Modified nozzle configuration (six holes) reduced the Nox emissions for a B20 biodiesel-diesel blend in a diesel engine. It was observed that Nox formation was reduced from $7.4 \mathrm{~g} / \mathrm{kW}-\mathrm{hr}$ with the base nozzle configuration to $6.6 \mathrm{~g} / \mathrm{kW}$-hr with modified nozzle configuration due to the reduction in penetration distance and reduced cylinder temperature. There were tangible benefits of reduction in other emissions as well [122].

\subsection{Split Injection}

Nowadays, customers wish to have their engines more efficient and at the same time Governments are implementing strict emissions norms. These specific demands can be met by replacing the mechanical fuel supply system with electronic fuel supply. Today's engines are as much electronic as they are mechanical [123]. The literature review on the development of advanced injection strategies emphasizes the importance of an electronically operated fuel injection system. The authors described the electronically operated fuel injection system as the heart of an engine in these years for improved performance and low emissions [124].

Split injection term is also referred to as multiple injection, wherein the injection is divided into two smaller injections, i.e., pre-injection and main injection [108,125]. The split injection strategies also include change of injection pressure, injection timing and injection interval [125]. Split injection has been considered as an effective way to tackle the problems associated with exhaust emissions, especially the formation of Nox and particulate matter from diesel engines without adding more complexity to the existing engine [126-130]. The effects of split injection on flame temperature and soot distribution were studied on biodiesel and diesel as the fuels in an optical CI engine by both numerically and experimentally at different injection timings and quantities. It was concluded that the biodiesel-fueled engine developed a higher flame temperature and lower soot formation than its counterpart diesel-fueled engine. The higher flame temperature could be reduced by increasing the pilot fuel mass. It is known that biodiesel properties have a negative impact on the spray development, but split injection allows for biodiesel fuel injection to reduce the exhaust emissions and improve the atomization of biodiesel and hence better mixing with air [131]. The tests conducted by using different blends of Karanja biodiesel in the single common rail direct injection (CRDI) research engine showed higher BSFC and BTE for higher biodiesel concentrated blend. However, lower concentrated biodiesel-diesel blends produced lower emissions such as brake specific carbon monoxide (BSCO) and brake specific hydrocarbon (BSHC) emissions than diesel but with increased Nox [132]. The experiments conducted to study the impact of advanced injection strategies on CRDI engine by using biodiesel showed an improved engine performance with less emissions including Nox [107]. The formation of Nox was decreased considerably in a soybean biodiesel engine by recirculating the exhaust gas (EGR), but BSFC and soot formation increased slightly [133]. Optimum double-injection strategy was recently implemented after having a parametric study for B20 biodiesel made from waste cooking oil. This strategy also reduced the formation of Nox but with higher particulate matter compared to a diesel engine [134]. There are two studies carried out on the same diesel engine and using coconut oil methyl esters and diesel blends by implementing two-stage and triple-stage injection strategies. The strategies produced lesser Nox and smoke simultaneously $[135,136]$. The engine used for the tests has been shown in Figure 6. 


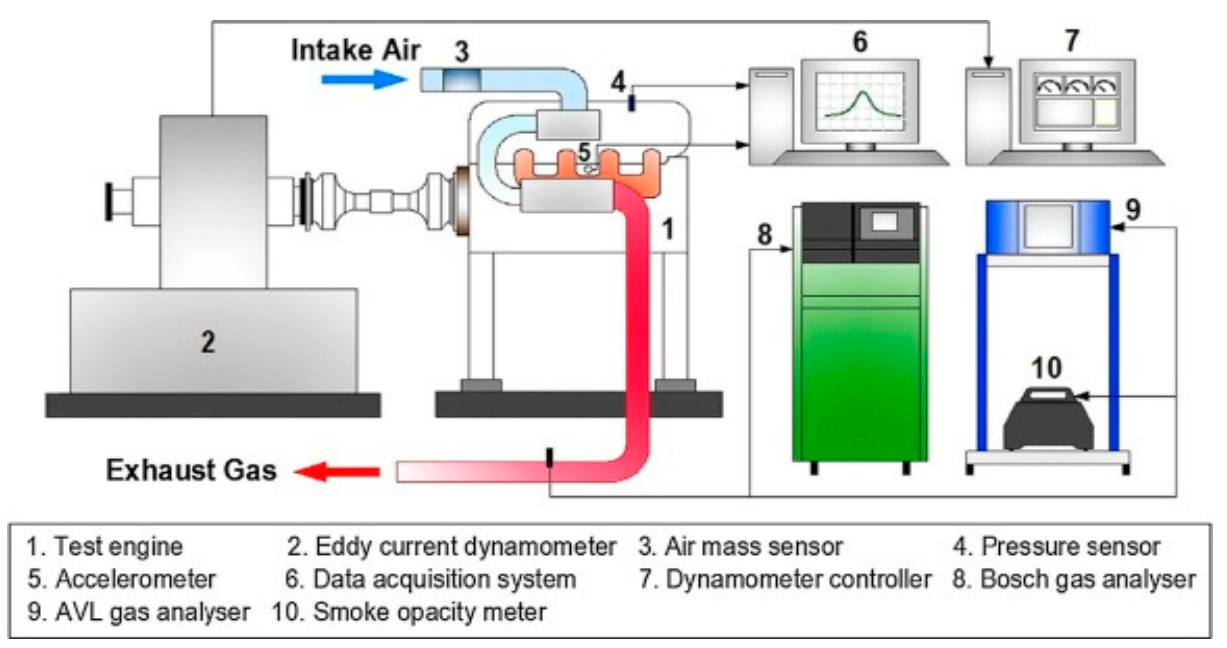

Figure 6. Engine multi-stage injection.

It is observed that split injection can prove to be the recommended method in diesel engines as far as Nox reduction is concerned. However, the use of split injection in biodiesel does not follow the trend of that of the diesel engine. In fact, the use of split injection for biodiesel has worsened Nox formation [132]. Thus, it can be inferred that there are some other strategies that need to be implemented, such as EGR and triple-stage injection [107,131,133-136]. Triple-stage injection in particular has proved to be more effective in controlling Nox as well as other emissions simultaneously [135]. This should prompt researchers to try even for four-or-more-stage injection. Similarly, other strategies, such as water injection, steam injection, etc., could be an interesting choice to be tested.

\subsection{Solenoid Injector}

Today, every modern engine is managed by an electronic control unit (ECU) module. Therefore, a lot of research is being spent on implementing the ECU-based fuel supply to increase the performance of an engine with reduced emissions. This has also increased the complexity of the engine design and its cost. In order to develop an efficient engine with lesser emissions, a very sophisticated fuel injection process is required [11,137-139]. The performance, combustion noise and emissions of an engine depend mainly on the accuracy at which the quantity of fuel is supplied at an elevated injection pressure [140-145]. Solenoid-driven injectors are widely used in the common rail direct injection (CRDI) engines for a desired fuel injection process. The solenoid technology is reliable and cost effective [146-148]. The effect of diesel and biodiesel on the hydraulic behavior of a solenoid-operated common rail injection system was studied by a one-dimensional model. The study was carried out by characterizing the different injector components. Both single and multiple injection strategies were analyzed for diesel and rapeseed biodiesel fuels. Finally, the authors proposed a modification in the geometry of the injector for the biodiesel-fueled engine to get the performance of the biodiesel engine on par with that of the standard diesel engine. The authors tested the engine with the modified configuration by using biodiesel as a fuel. It was concluded that the modified injector with high injection pressure showed similar results to the one obtained by the standard diesel-fueled engine. Furthermore, the main plus post-injection strategies also gave similar results when they were compared with diesel fuel [149]. A combination of experimental and computational methods has been carried out by Payri et al. [150] to evaluate the influence of rape methyl ester (RME) biodiesel physical properties on the injection process on the CRDI engine at different injection strategies, including main injection and main plus post injection. They found some important differences in the diesel and biodiesel, especially at low injection pressure. However, they proposed modifications in the hardware to rectify the differences [150]. 


\subsection{Piston Bowl}

The angular momentum of air developed inside the intake manifold decays during the suction and end of compression stroke due to friction at the walls and turbulent dissipation within the fluid. However, swirl in the cylinder can be maintained and improved further by designing the combustion chamber suitably, such as a compact bowl-in-piston combustion chamber [151,152]. This swirl increases the heat transfer, evaporation, mixing and combustion rates. The shape of combustion chamber plays an important role in generating the swirl and maximum turbulence leading to desired rapid combustion [152-155]. The combined effect of different engine variables and geometries of the piston bowl was studied recently. First of all, the engine variables, such as injection opening pressure, injection timing, nozzle holes and compression ratio, were optimized to $230 \mathrm{bar}, 26$ degree before top dead center (BTDC), 18 and five holes, respectively. The performance tests were conducted on diesel engine by using B20 dairy scum biodiesel-diesel blend for different types of combustion chamber geometries at optimum engine operating conditions. It was found that Re-entrant Toroidal Piston Bowl Geometry (RTPBG) resulted in improved performance, combustion and reduced emission characteristics compared to other types of piston bowl geometries [156]. Figure 7 shows the summery of modifications done in fuel injection system.

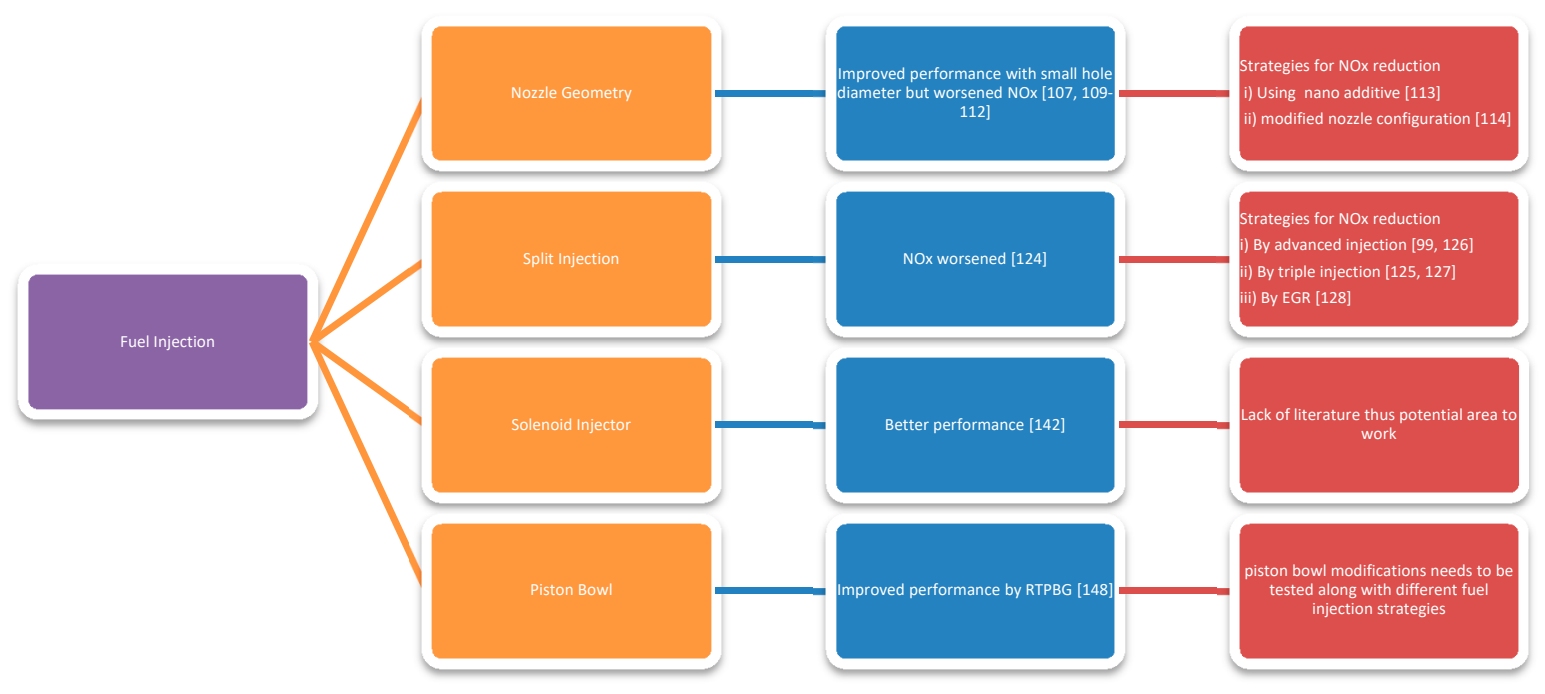

Figure 7. Schematic diagram of fuel injection modifications.

\section{Exhaust Manifold}

At the end of power stroke when the exhaust valve opens the cylinder pressure is much higher than that of exhaust manifold pressure. So, the burnt gases flow out of the cylinder through the exhaust valve into the exhaust manifold until the cylinder pressure and exhaust manifold pressure are same. The exhaust system typically consists of an exhaust manifold, exhaust pipe, often a catalytic converter for emission control [11].

\section{Exhaust Gas Recycle (EGR)}

The exhaust gas recycle (EGR) is a technique to minimize the formation of NOx in IC engines [157-160]. A fraction of the exhaust gases is recycled through a control valve from the exhaust to the engine intake manifold, which reduces the cylinder temperature and hence the quantity of Nox being formed is reduced [161-165]. It is an established fact that biodiesel engines produce more Nox, hence many researchers have studied the effect of EGR in reducing the Nox formation. The effect of EGR on the diesel engine was studied using palm biodiesel. It was found that the Nox formation reduced significantly due to lower cylinder temperature, but fuel consumption and other emissions increased [166]. The higher rate of EGR is necessary for low temperature combustion for biodiesel engines [167]. The tests in a 
single cylinder, direct injection, four-stroke diesel engine using soybean biodiesel-diesel blend B20 at different loading conditions and constant speed with various EGR rates showed a reduction of $55 \%$ and $15 \%$ in the formation of Nox and smoke, respectively, at a high engine load. However, the specific fuel consumption increased and thermal efficiency reduced [168]. The higher premixed combustion phase was attributed for an increase in the higher NOx concentrations when cottonseed B20 biodiesel was used as fuel in a single-cylinder diesel engine with a power rating of $3 \mathrm{~kW}$ and at a constant speed of $1500 \mathrm{rpm}$. However, utilizing a small quantity of EGR could reduce the NOx concentrations. A higher quantity of EGR could reduce the engine efficiency and increase the fuel consumption [169]. Similar type of results and trends were obtained with respect to NOx and performance when EGR was used for dual fuel engines as well $[170,171]$. Some researchers have obtained the desired low NOx emissions without compromising on the performance by implementing different techniques [172,173]. Experiments were conducted by using the blend of Calophyllum Inophyllum biodiesel, $\mathrm{TiO} 2$ nano additives and EGR. A dosage of $40 \mathrm{ppm}$

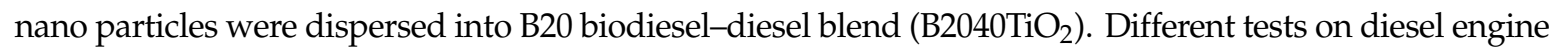
were conducted by using different combinations of biodiesel, nano additives and EGR, such as B20, $\mathrm{B}_{2040 T i O}, \mathrm{~B} 20+20 \% \mathrm{EGR}, \mathrm{B}_{2040 \mathrm{TiO}_{2}}+20 \% \mathrm{EGR}$ at different engine loading conditions. The brake thermal efficiency of the engine increased by $3.1 \%$ when biodiesel-diesel-nano additives blend was used as fuel. When the combination of biodiesel-diesel-nano additives blend and EGR was used, the thermal efficiency was found to increase by $2.5 \%$. However, when only the biodiesel-diesel-EGR combination was used, the thermal efficiency decreased by $1.8 \%$. The overall performance of the engine with reduced emissions was found when the EGR was coupled to the engine and the blend of Calophyllum Inophyllum biodiesel-diesel-nano additives was used as the fuel [172]. Selective Catalytic Reduction (SCR) technique is a lean NOX after-treatment technology [174]. It has been used to reduce the NOx formation in biodiesel engines. The engine was run at a constant speed of $1500 \mathrm{rpm}, 20^{\circ} \mathrm{BTDC}$ of injection timing and an injection opening pressure of 250 bar by using Mahua biodiesel and its blend. Figure 8 shows the typical SCR used in a single-cylinder diesel engine.

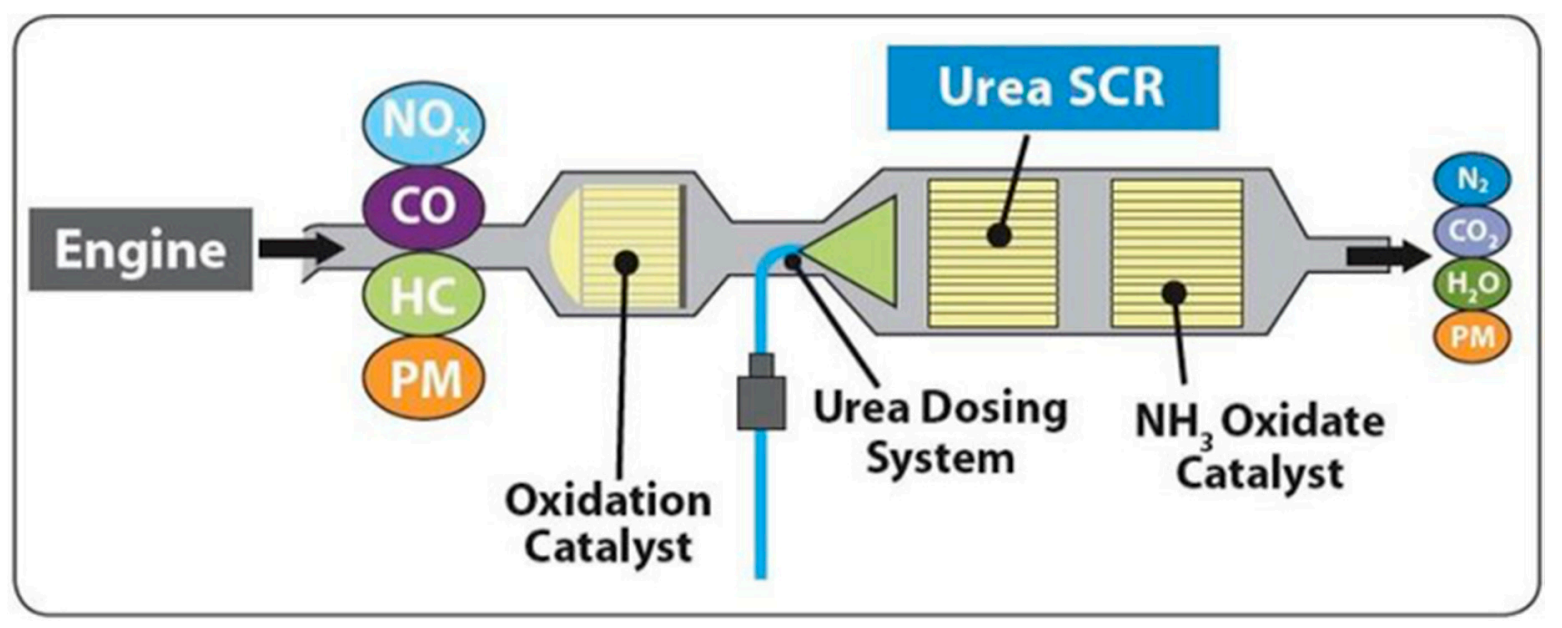

Figure 8. Schematic diagram of Selective Catalytic Reduction (SCR) geometry.

The results obtained show that SCR gives a substantial reduction in oxides of nitrogen in combination with cold and hot exhaust gas recirculation [173]. The EGR is one of the techniques to curtail the formation of NOx, which is successfully implemented. However, the adoption of EGR alone has a negative impact on the engine performance, leading to reduced thermal efficiency and higher specific fuel consumption. The negative impact of EGR in terms of reduced thermal efficiency and specific fuel consumption can be overcome by using nano additives in biodiesel-diesel blend or Selective Catalytic Reduction (SCR) in the exhaust manifold. Figure 9 represents the modifications carried out in exhaust manifold. 


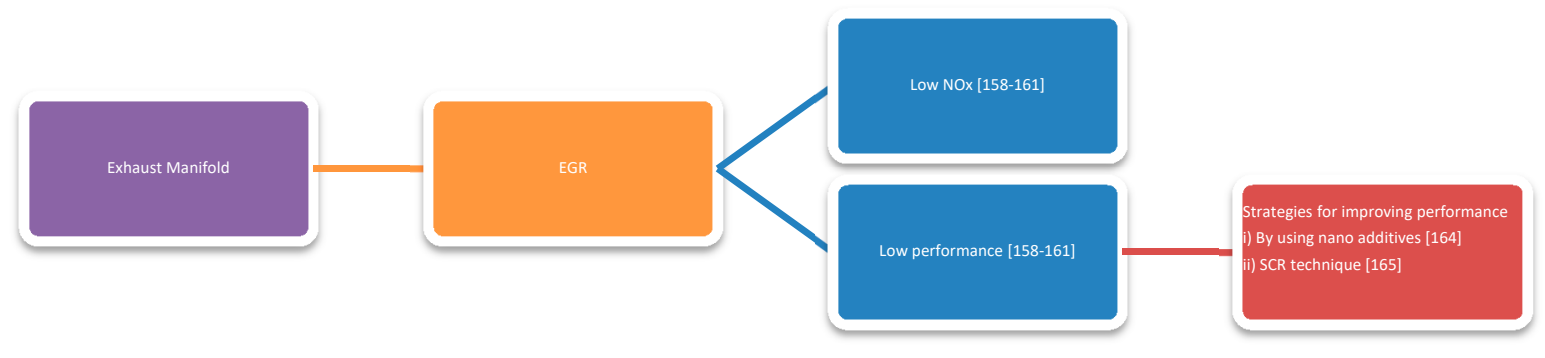

Figure 9. Schematic diagram of Exhaust manifold modifications.

\section{Conclusions}

The continuous demand of human comfort has put lot of pressure on the transportation sector. However, the decreasing and environmental issues have compelled scientists and researchers to look for new designs of IC engines to boost its performance by using not only fossil fuels but other alternate fuels, such as biodiesel. It should be comprehensively understood that the IC engine will remain the backbone of the transportation sector at least for a few decades to follow. Thus, any improvement in the IC engine design to enhance its efficiency and reduce the emissions would be very much desirable as well as appreciable. The current article gives an updated review of such attempts to improve the performance of the IC engine fueled by biodiesel. The following conclusions can be drawn from this article.

- Modifications in the intake manifold lead to a higher concentration of NOx but it can be minimized by using different techniques, such as water injection, steam injection, bioethanol addition, antioxidants in fuel and EGR.

- Split injection and small-hole diameter nozzle geometry give better performance with increased NOx but implementing triple injection, using an RTPBG combustion chamber, reduces NOx.

- A low rate of EGR minimizes the formation of NOx without affecting performance.

Funding: This work was funded by King Khalid University under the grant number R.G.P. 2/107/41.

Acknowledgments: The author extend his appreciation to the Deanship of Scientific Research at King Khalid University for funding this work through research groups program under grant number (R.G.P 2/107/41).

Conflicts of Interest: The author declares no conflict of interest.

\section{References}

1. Barreto, R.A. Fossil fuels, alternative energy and economic growth. Econ. Model. 2018, 75, 196-220. [CrossRef]

2. Smil, V. Energy Transitions: History, Requirements, Prospects; ABC-CLIO: Santa Barbara, CA, USA, 2010.

3. Kumar, N.; Varun; Chauhan, S.R. Performance and emission characteristics of biodiesel from different origins: A review. Renew. Sustain. Energy Rev. 2013, 21, 633-658. [CrossRef]

4. Ong, Y.K.; Bhatia, S. The current status and perspectives of biofuel production via catalytic cracking of edible and non-edible oils. Energy 2010, 35, 111-119. [CrossRef]

5. Khan, T.Y.; Atabani, A.; Badruddin, I.A.; Badarudin, A.; Khayoon, M.; Triwahyono, S. Recent scenario and technologies to utilize non-edible oils for biodiesel production. Renew. Sustain. Energy Rev. 2014, 37, 840-851. [CrossRef]

6. Atabani, A.E.; Mahlia, T.M.I.; Masjuki, H.H.; Badruddin, I.A.; Yussof, H.W.; Chong, W.T.; Lee, K.T. A comparative evaluation of physical and chemical properties of biodiesel synthesized from edible and non-edible oils and study on the effect of biodiesel blending. Energy 2013, 58, 296-304. [CrossRef]

7. Khan, T.Y.; Atabani, A.; Badruddin, I.A.; Ankalgi, R.; Badarudin, A. Ceiba pentandra, Nigella sativa and their blend as prospective feedstocks for biodiesel. Ind. Crop. Prod. 2015, 65, 367-373. [CrossRef]

8. Lanjekar, R.D.; Deshmukh, D. A review of the effect of the composition of biodiesel on NOx emission, oxidative stability and cold flow properties. Renew. Sustain. Energy Rev. 2016, 54, 1401-1411. [CrossRef] 
9. Anwar, A.; Garforth, A. Challenges and opportunities of enhancing cold flow properties of biodiesel via heterogeneous catalysis. Fuel 2016, 173, 189-208. [CrossRef]

10. Dwivedi, G.; Sharma, M. Impact of cold flow properties of biodiesel on engine performance. Renew. Sustain. Energy Rev. 2014, 31, 650-656. [CrossRef]

11. Heywood, J.B. Internal Combustion Engine Fundamentals; McGraw-Hill Book Company: New York, NY, USA, 1988.

12. Noor, C.M.; Noor, M.; Mamat, R. Biodiesel as alternative fuel for marine diesel engine applications: A review. Renew. Sustain. Energy Rev. 2018, 94, 127-142. [CrossRef]

13. Suresh, M.; Jawahar, C.; Richard, A. A review on biodiesel production, combustion, performance, and emission characteristics of non-edible oils in variable compression ratio diesel engine using biodiesel and its blends. Renew. Sustain. Energy Rev. 2018, 92, 38-49. [CrossRef]

14. Soudagar, M.E.M.; Sabri, M.F.M.; Kalam, M.; Badruddin, I.; Banapurmath, N.; Akram, N. The effect of nano-additives in diesel-biodiesel fuel blends: A comprehensive review on stability, engine performance and emission characteristics. Energy Convers. Manag. 2018, 178, 146-177. [CrossRef]

15. Ramalingam, S.; Rajendran, S.; Ganesan, P.; Govindasamy, M. Effect of operating parameters and antioxidant additives with biodiesels to improve the performance and reducing the emissions in a compression ignition engine-A review. Renew. Sustain. Energy Rev. 2018, 81, 775-788. [CrossRef]

16. Hosseinzadeh-Bandbafha, H.; Tabatabaei, M.; Aghbashlo, M.; Khanali, M.; Demirbas, A. A comprehensive review on the environmental impacts of diesel/biodiesel additives. Energy Convers. Manag. 2018, 174, 579-614. [CrossRef]

17. Ambat, I.; Srivastava, V.; Sillanpää, M. Recent advancement in biodiesel production methodologies using various feedstock: A review. Renew. Sustain. Energy Rev. 2018, 90, 356-369. [CrossRef]

18. Goel, V.; Kumar, N.; Singh, P. Impact of modified parameters on diesel engine characteristics using biodiesel: A review. Renew. Sustain. Energy Rev. 2018, 82, 2716-2729. [CrossRef]

19. Khan, T.Y.; Badruddin, I.A.; Badarudin, A.; Banapurmath, N.; Ahmed, N.S.; Quadir, G.; Al-Rashed, A.A.; Khaleed, H.; Kamangar, S. Effects of engine variables and heat transfer on the performance of biodiesel fueled IC engines. Renew. Sustain. Energy Rev. 2015, 44, 682-691. [CrossRef]

20. Varun; Singh, P.; Tiwari, S.K.; Singh, R.; Kumar, N. Modification in combustion chamber geometry of CI engines for suitability of biodiesel: A review. Renew. Sustain. Energy Rev. 2017, 79, 1016-1033. [CrossRef]

21. Rocha, H.M.Z.; Pereira, R.D.S.; Nogueira, M.F.M.; Belchior, C.R.P.; Tostes, M.E.D.L. Experimental investigation of hydrogen addition in the intake air of compressed ignition engines running on biodiesel blend. Int. J. Hydrog. Energy 2017, 42, 4530-4539. [CrossRef]

22. Aldhaidhawi, M.; Chiriac, R.; Bădescu, V.; Descombes, G.; Podevin, P. Investigation on the mixture formation, combustion characteristics and performance of a Diesel engine fueled with Diesel, Biodiesel B20 and hydrogen addition. Int. J. Hydrog. Energy 2017, 42, 16793-16807. [CrossRef]

23. Chelladorai, P.; Varuvel, E.G.; Martin, L.J.; Bedhannan, N. Synergistic effect of hydrogen induction with biofuel obtained from winery waste (grapeseed oil) for CI engine application. Int. J. Hydrog. Energy 2018, 43, 12473-12490. [CrossRef]

24. Baltacioglu, M.K.; Arat, H.T.; Özcanlı, M.; Aydin, K.; Özcanlı, M.; Aydın, K. Experimental comparison of pure hydrogen and HHO (hydroxy) enriched biodiesel (B10) fuel in a commercial diesel engine. Int. J. Hydrog. Energy 2016, 41, 8347-8353. [CrossRef]

25. Parthasarathy, M.; Lalvani, J.I.J.; Dhinesh, B.; Annamalai, K.; Balasubramanian, D. Effect of hydrogen on ethanol-biodiesel blend on performance and emission characteristics of a direct injection diesel engine. Ecotoxicol. Environ. Saf. 2016, 134, 433-439. [CrossRef]

26. Aydin, K.; Kenanoğlu, R. Effects of hydrogenation of fossil fuels with hydrogen and hydroxy gas on performance and emissions of internal combustion engines. Int. J. Hydrog. Energy 2018, 43, 14047-14058. [CrossRef]

27. Chiriac, R.; Apostolescu, N. Emissions of a diesel engine using B20 and effects of hydrogen addition. Int. J. Hydrog. Energy 2013, 38, 13453-13462. [CrossRef]

28. Sukjit, E.; Herreros, J.M.; Dearn, K.D.; Tsolakis, A.; Theinnoi, K. Effect of hydrogen on butanol-biodiesel blends in compression ignition engines. Int. J. Hydrog. Energy 2013, 38, 1624-1635. [CrossRef]

29. Yaliwal, V.; Banapurmath, N.; Hosmath, R.; Khandal, S.V.; Budzianowski, W. Utilization of hydrogen in low calorific value producer gas derived from municipal solid waste and biodiesel for diesel engine power generation application. Renew. Energy 2016, 99, 1253-1261. [CrossRef] 
30. Korakianitis, T.; Namasivayam, A.; Crookes, R. Hydrogen dual-fuelling of compression ignition engines with emulsified biodiesel as pilot fuel. Int. J. Hydrog. Energy 2010, 35, 13329-13344. [CrossRef]

31. Chandra, R.; Kumar, R. Fuel Properties of Some Stable Alcohol-Diesel Microemulsions for Their Use in Compression Ignition Engines. Energy Fuels 2007, 21, 3410-3414. [CrossRef]

32. Attaphong, C.; Sabatini, D.A. Phase Behaviors of Vegetable Oil-Based Microemulsion Fuels: The Effects of Temperatures, Surfactants, Oils, and Water in Ethanol. Energy Fuels 2013, 27, 6773-6780. [CrossRef]

33. Ashihmin, A.; Piskunov, M.V.; Roisman, I.; Yanovsky, V. Thermal stability control of the water-in-diesel microemulsion fuel produced by using a nonionic surfactant combined with aliphatic alcohols. J. Dispers. Sci. Technol. 2019, 41, 771-778. [CrossRef]

34. Ashikhmin, A.; Piskunov, M.V.; Yanovsky, V.A.; Yan, W.-M. Properties and Phase Behavior of Water-in-Diesel Microemulsion Fuels Stabilized by Nonionic Surfactants in Combination with Aliphatic Alcohol. Energy Fuels 2020, 34, 2135-2142. [CrossRef]

35. Heidari, S.; Najjar, R.; Burnens, G.; Awad, S.; Tazerout, M. Experimental Investigation of Emission, Combustion, and Energy Performance of a Novel Diesel/Colza Oil Fuel Microemulsion in a Direct-Injection Diesel Engine. Energy Fuels 2018, 32, 10923-10932. [CrossRef]

36. Perumal, V.; Ilangkumaran, M. Water emulsified hybrid pongamia biodiesel as a modified fuel for the experimental analysis of performance, combustion and emission characteristics of a direct injection diesel engine. Renew. Energy 2018, 121, 623-631. [CrossRef]

37. Cecrle, E.; Depcik, C.; Guo, J.; Peltier, E. Analysis of the effects of reformate (hydrogen/carbon monoxide) as an assistive fuel on the performance and emissions of used canola-oil biodiesel. Int. J. Hydrog. Energy 2012, 37, 3510-3527. [CrossRef]

38. Ma, X.; Zhang, F.; Han, K.; Zhu, Z.; Liu, Y. Effects of Intake Manifold Water Injection on Combustion and Emissions of Diesel Engine. Energy Procedia 2014, 61, 777-781. [CrossRef]

39. Mohapatra, D.; Swain, R.K.; Jena, S.P.; Acharya, S.K.; Patnaik, P.P. Effect of steam injection and FeCl3 as fuel additive on performance of thermal barrier coated diesel engine. Sustain. Environ. Res. 2018, 28, 247-255. [CrossRef]

40. Patnaik, P.; Acharya, S.; Padhi, D.; Mohanty, U. Experimental investigation on CI engine performance using steam injection and ferric chloride as catalyst. Eng. Sci. Technol. Int. J. 2016, 19, 2073-2080. [CrossRef]

41. Zhang, Z.; Kang, Z.; Jiang, L.; Chao, Y.; Deng, J.; Hu, Z.; Li, L.; Wu, Z. Effect of direct water injection during compression stroke on thermal efficiency optimization of common rail diesel engine. Energy Procedia 2017, 142, 1251-1258. [CrossRef]

42. Taghavifar, H.; Anvari, S.; Parvishi, A. Benchmarking of water injection in a hydrogen-fueled diesel engine to reduce emissions. Int. J. Hydrog. Energy 2017, 42, 11962-11975. [CrossRef]

43. Şahin, Z.; Tuti, M.; Durgun, O. Experimental investigation of the effects of water adding to the intake air on the engine performance and exhaust emissions in a DI automotive diesel engine. Fuel 2014, 115, 884-895. [CrossRef]

44. Tesfa, B.C.; Mishra, R.; Gu, F.; Ball, A.D. Water injection effects on the performance and emission characteristics of a CI engine operating with biodiesel. Renew. Energy 2012, 37, 333-344. [CrossRef]

45. Parlak, A. A study on performance and exhaust emissions of the steam injected DI diesel engine running with different diesel- conola oil methyl ester blends. J. Energy Inst. 2019, 92, 717-729. [CrossRef]

46. Mohankumar, S.; Senthilkumar, P. Particulate matter formation and its control methodologies for diesel engine: A comprehensive review. Renew. Sustain. Energy Rev. 2017, 80, 1227-1238. [CrossRef]

47. Imran, A.; Varman, M.; Masjuki, H.; Kalam, M. Review on alcohol fumigation on diesel engine: A viable alternative dual fuel technology for satisfactory engine performance and reduction of environment concerning emission. Renew. Sustain. Energy Rev. 2013, 26, 739-751. [CrossRef]

48. Ghadikolaei, M.A. Effect of alcohol blend and fumigation on regulated and unregulated emissions of IC engines-A review. Renew. Sustain. Energy Rev. 2016, 57, 1440-1495. [CrossRef]

49. Telli, G.D.; Altafini, C.; Rosa, J.S.; Costa, C.A. Experimental investigation of a compression ignition engine operating on B7 direct injected and hydrous ethanol fumigation. Energy 2018, 165, 106-117. [CrossRef]

50. Geo, V.E.; Sonthalia, A.; Nagarajan, G.; Nagalingam, B. Studies on performance, combustion and emission of a single cylinder diesel engine fuelled with rubber seed oil and its biodiesel along with ethanol as injected fuel. Fuel 2017, 209, 733-741. [CrossRef] 
51. Krishna, M.M.; Prakash, T.O.; Ushasri, P.; Janardhan, N.; Murthy, P. Experimental investigations on direct injection diesel engine with ceramic coated combustion chamber with carbureted alcohols and crude jatropha oil. Renew. Sustain. Energy Rev. 2016, 53, 606-628. [CrossRef]

52. Hansdah, D.; Sivalingam, M. Bioethanol fumigation in a DI diesel engine. Fuel 2014, 130, 324-333. [CrossRef]

53. Tutak, W. Bioethanol E85 as a fuel for dual fuel diesel engine. Energy Convers. Manag. 2014, 86, 39-48. [CrossRef]

54. Goldsworthy, L. Fumigation of a heavy duty common rail marine diesel engine with ethanol-water mixtures. Exp. Therm. Fluid Sci. 2013, 47, 48-59. [CrossRef]

55. Kane, R.D.; Eden, D.; Sridhar, N.; Maldonado, J.; Brongers, P.E.; Michaiel, P.H.; Agarwal, A.K.; Beavers, J.A. Stress Corrosion Cracking of Carbon Steel in Fuel Grade Ethanol: Review, Experience, Survey, Field Monitoring, and Laboratory Testing: Downstream Segment; American Petroleum Institute: Washington, DC, USA, 2007.

56. Joseph, O.O. Structural Integrity of Materials in Fuel Ethanol Environments, in Alcohol Fuels-Current Technologies and Future Prospect; IntechOpen: London, UK, 2019.

57. Şahin, Z.; Kurt, M.; Durgun, O. Experimental investigation of gasoline fumigation for different compression ratios in a diesel engine. Energy Procedia 2018, 147, 268-276. [CrossRef]

58. Şahin, Z.; Durgun, O. Improving of diesel combustion-pollution-fuel economy and performance by gasoline fumigation. Energy Convers. Manag. 2013, 76, 620-633. [CrossRef]

59. Hoseinpour, M.; Sadrnia, H.; Tabasizadeh, M.; Ghobadian, B. Evaluation of the effect of gasoline fumigation on performance and emission characteristics of a diesel engine fueled with B20 using an experimental investigation and TOPSIS method. Fuel 2018, 223, 277-285. [CrossRef]

60. Hoseinpour, M.; Sadrnia, H.; Tabasizadeh, M.; Ghobadian, B. Energy and exergy analyses of a diesel engine fueled with diesel, biodiesel-diesel blend and gasoline fumigation. Energy 2017, 141, 2408-2420. [CrossRef]

61. Calik, A.T.; Taskiran, O.O.; Mehdiyev, R. Numerical investigation of twin swirl application in diesel engine combustion. Fuel 2018, 224, 101-110. [CrossRef]

62. Rakopoulos, C.D.; Kosmadakis, G.; Pariotis, E.G. Investigation of piston bowl geometry and speed effects in a motored HSDI diesel engine using a CFD against a quasi-dimensional model. Energy Convers. Manag. 2010, 51, 470-484. [CrossRef]

63. Musa, O.; Xiong, C.; ChangSheng, Z. Experimental and numerical investigation on the ignition and combustion stability in solid fuel ramjet with swirling flow. Acta Astronaut. 2017, 137, 157-167. [CrossRef]

64. Bari, S.; Saad, I. Performance and emissions of a compression ignition (CI) engine run with biodiesel using guide vanes at varied vane angles. Fuel 2015, 143, 217-228. [CrossRef]

65. Bari, S.; Saad, I. Effect of guide vane height on the performance and emissions of a compression ignition (CI) engine run with biodiesel through simulation and experiment. Appl. Energy 2014, 136, 431-444. [CrossRef]

66. Bari, S.; Johansen, P.; Alherz, A. Simulation of Improvements to In-cylinder Mixing of Biodiesel with Air by Incorporating Guide Vanes into the Air Intake System. Procedia Eng. 2015, 105, 480-487. [CrossRef]

67. Bari, S.; Saad, I. Optimization of vane numbers through simulation and experiment, and investigation of the effect on the performance and emissions of a CI (compression ignition) engine run with biodiesel. Energy 2015, 79, 248-263. [CrossRef]

68. Bari, S.; Saad, I. CFD modelling of the effect of guide vane swirl and tumble device to generate better in-cylinder air flow in a CI engine fuelled by biodiesel. Comput. Fluids 2013, 84, 262-269. [CrossRef]

69. Saad, I.; Bari, S.; Hossain, S. In-Cylinder Air Flow Characteristics Generated by Guide Vane Swirl and Tumble Device to Improve Air-Fuel Mixing in Diesel Engine Using Biodiesel. Procedia Eng. 2013, 56, 363-368. [CrossRef]

70. Saad, I.; Bari, S. Guide Vane Swirl and Tumble Device to Improve in-cylinder Air Flow of CI Engine Using Vegetable Oil. Procedia Eng. 2014, 90, 425-430. [CrossRef]

71. Subramanian, K. A comparison of water-diesel emulsion and timed injection of water into the intake manifold of a diesel engine for simultaneous control of NO and smoke emissions. Energy Convers. Manag. 2011, 52, 849-857. [CrossRef]

72. Tauzia, X.; Maiboom, A.; Shah, S.R. Experimental study of inlet manifold water injection on combustion and emissions of an automotive direct injection Diesel engine. Energy 2010, 35, 3628-3639. [CrossRef]

73. Kumarappa, S.; Prabhukumar, G.P. Improving the performance of two stroke spark ignition engine by direct electronic CNG injection. Jordan J. Mech. Ind. Eng. 2008, 2, 169-174.

74. Hazar, H. Effects of biodiesel on a low heat loss diesel engine. Renew. Energy 2009, 34, 1533-1537. [CrossRef] 
75. Hazar, H. Cotton methyl ester usage in a diesel engine equipped with insulated combustion chamber. Appl. Energy 2010, 87, 134-140. [CrossRef]

76. Hazar, H.; Öztürk, U. The effects of Al2O3-TiO2 coating in a diesel engine on performance and emission of corn oil methyl ester. Renew. Energy 2010, 35, 2211-2216. [CrossRef]

77. Chan, S.H.; Khor, K.A. The Effect of Thermal Barrier Coated Piston Crown on Engine Characteristics. J. Mater. Eng. Perform. 2000, 9, 103-109. [CrossRef]

78. Schulz, U.; Leyens, C.; Fritscher, K.; Peters, M.; Saruhan-Brings, B.; Lavigne, O.; Dorvaux, J.-M.; Poulain, M.; Mévrel, R.; Caliez, M. Some recent trends in research and technology of advanced thermal barrier coatings. Aerosp. Sci. Technol. 2003, 7, 73-80. [CrossRef]

79. Peters, M.; Leyens, C.; Schulz, U.; Kaysser, W.A. EB-PVD Thermal Barrier Coatings for Aeroengines and Gas Turbines. Adv. Eng. Mater. 2001, 3, 193-204. [CrossRef]

80. Yao, M.; Ma, T.; Wang, H.; Zheng, Z.; Liu, H.-F.; Zhang, Y. A theoretical study on the effects of thermal barrier coating on diesel engine combustion and emission characteristics. Energy 2018, 162, 744-752. [CrossRef]

81. Karthickeyan, V. Effect of cetane enhancer on Moringa oleifera biodiesel in a thermal coated direct injection diesel engine. Fuel 2019, 235, 538-550. [CrossRef]

82. Aydın, S.; Sayın, C. Impact of thermal barrier coating application on the combustion, performance and emissions of a diesel engine fueled with waste cooking oil biodiesel-diesel blends. Fuel 2014, 136, 334-340. [CrossRef]

83. Aydin, S.; Sayin, C.; Aydin, H.; Aydin, H. Investigation of the usability of biodiesel obtained from residual frying oil in a diesel engine with thermal barrier coating. Appl. Therm. Eng. 2015, 80, 212-219. [CrossRef]

84. Balat, M.; Balat, H. Progress in biodiesel processing. Appl. Energy 2010, 87, 1815-1835. [CrossRef]

85. Lin, L.; Cunshan, Z.; Vittayapadung, S.; Xiangqian, S.; Dong, M. Opportunities and challenges for biodiesel fuel. Appl. Energy 2011, 88, 1020-1031. [CrossRef]

86. Szabados, G.; Bereczky, Á. Experimental investigation of physicochemical properties of diesel, biodiesel and TBK-biodiesel fuels and combustion and emission analysis in CI internal combustion engine. Renew. Energy 2018, 121, 568-578. [CrossRef]

87. Sani, S.; Kaisan, M.U.; Kulla, D.; Obi, A.; Jibrin, A.; Ashok, B. Determination of physico chemical properties of biodiesel from Citrullus lanatus seeds oil and diesel blends. Ind. Crop. Prod. 2018, 122, 702-708. [CrossRef]

88. Aminian, A.; Zarenezhad, B. Accurate predicting the viscosity of biodiesels and blends using soft computing models. Renew. Energy 2018, 120, 488-500. [CrossRef]

89. Du, E.; Cai, L.; Huang, K.; Tang, H.; Xu, X.; Tao, R. Reducing viscosity to promote biodiesel for energy security and improve combustion efficiency. Fuel 2018, 211, 194-196. [CrossRef]

90. Gülüm, M.; Bilgin, A. A comprehensive study on measurement and prediction of viscosity of biodiesel-diesel-alcohol ternary blends. Energy 2018, 148, 341-361. [CrossRef]

91. Gulum, M.; Bilgin, A.; Cakmak, A. Comparison of optimum reaction parameters of corn oil biodiesels produced by using sodium hydroxide $(\mathrm{NaOH})$ and potassium hydroxide (KOH). J. Fac. Eng. Archit. Gazi Univ. 2015, 30, 503-511.

92. Gülüm, M.; Bilgin, A. Two-term power models for estimating kinematic viscosities of different biodiesel-diesel fuel blends. Fuel Process. Technol. 2016, 149, 121-130. [CrossRef]

93. Gülüm, M.; Bilgin, A. Density, flash point and heating value variations of corn oil biodiesel-diesel fuel blends. Fuel Process. Technol. 2015, 134, 456-464. [CrossRef]

94. Hazar, H.; Aydin, H. Performance and emission evaluation of a CI engine fueled with preheated raw rapeseed oil (RRO)-diesel blends. Appl. Energy 2010, 87, 786-790. [CrossRef]

95. Prasad, C.M.V.; Krishna, M.V.S.M.; Reddy, C.P.; Mohan, K.R. Performance evaluation of non-edible vegetable oils as substitute fuels in low heat rejection diesel engines. Proc. Inst. Mech. Eng. Part D J. Automob. Eng. 2000, 214, 181-187. [CrossRef]

96. Mekonen, M.W.; Sahoo, N. Effect of fuel preheating with blended fuels and exhaust gas recirculation on diesel engine operating parameters. Renew. Energy Focus 2018, 26, 58-70. [CrossRef]

97. Prabu, S.S.; Asokan, M.; Prathiba, S.; Ahmed, S.; Puthean, G. Effect of additives on performance, combustion and emission behavior of preheated palm oil/diesel blends in DI diesel engine. Renew. Energy 2018, 122, 196-205. [CrossRef]

98. Yilmaz, N. Effects of intake air preheat and fuel blend ratio on a diesel engine operating on biodiesel-methanol blends. Fuel 2012, 94, 444-447. [CrossRef] 
99. Yehliu, K.; Boehman, A.L.; Armas, O. Emissions from different alternative diesel fuels operating with single and split fuel injection. Fuel 2010, 89, 423-437. [CrossRef]

100. Agarwal, A.K.; Singh, A.P.; Maurya, R.K.; Shukla, P.C.; Dhar, A.; Srivastava, D.K. Combustion characteristics of a common rail direct injection engine using different fuel injection strategies. Int. J. Therm. Sci. 2018, 134, 475-484. [CrossRef]

101. Ma, Z.; Huang, Z.; Li, C.; Wang, X.; Miao, H. Effects of Fuel Injection Timing on Combustion and Emission Characteristics of a Diesel Engine Fueled with Diesel-Propane Blends. Energy Fuels 2007, 21, 1504-1510. [CrossRef]

102. Agarwal, A.K.; Dhar, A.; Srivastava, D.K.; Maurya, R.K.; Singh, A.P. Effect of fuel injection pressure on diesel particulate size and number distribution in a CRDI single cylinder research engine. Fuel 2013, 107, 84-89. [CrossRef]

103. Zhao, L.; Torelli, R.; Zhu, X.; Scarcelli, R.; Som, S.; Schmidt, H.; Naber, J.; Lee, S.-Y. An Experimental and Numerical Study of Diesel Spray Impingement on a Flat Plate. SAE Int. J. Fuels Lubr. 2017, 10, 407-422. [CrossRef]

104. Qianjun, S.; He, W.; Wenhua, Z.; Bo, L.; Xia, Z.; Hang, X. Study on using electronic controlled fuel injection to improve the power performance of LPG fueled engine. Chin. Intern. Combust. Engine Eng. 2002, 5, 003.

105. Erkuş, B.; Surmen, A.; Karamangil, M.I. A comparative study of carburation and injection fuel supply methods in an LPG-fuelled SI engine. Fuel 2013, 107, 511-517. [CrossRef]

106. Kannan, G.; Anand, R. Effect of injection pressure and injection timing on DI diesel engine fuelled with biodiesel from waste cooking oil. Biomass Bioenergy 2012, 46, 343-352. [CrossRef]

107. Babu, D.; Karvembu, R.; Anand, R. Impact of split injection strategy on combustion, performance and emissions characteristics of biodiesel fuelled common rail direct injection assisted diesel engine. Energy 2018, 165, 577-592. [CrossRef]

108. Yang, K.; Nishida, K.; Ogata, Y.; Yamakawa, H. Characteristics of fuel evaporation, mixture formation and combustion of 2D cavity impinging spray under high-pressure split injection. Fuel 2018, 234, 746-756. [CrossRef]

109. Martínez-Martínez, S.; Sánchez-Cruz, F.; Riesco-Ávila, J.; Gallegos-Muñoz, A.; Aceves, S.M. Liquid penetration length in direct diesel fuel injection. Appl. Therm. Eng. 2008, 28, 1756-1762. [CrossRef]

110. Payri, R.; Garcia, J.; Salvador, F.; Gimeno, J.; Rubio, F.J.S. Using spray momentum flux measurements to understand the influence of diesel nozzle geometry on spray characteristics. Fuel 2005, 84, 551-561. [CrossRef]

111. Chen, Z.; He, Z.; Shang, W.; Duan, L.; Zhou, H.; Guo, G.; Guan, W. Experimental study on the effect of nozzle geometry on string cavitation in real-size optical diesel nozzles and spray characteristics. Fuel 2018, 232, 562-571. [CrossRef]

112. Schmidt, D.P.; Corradini, M.L. The internal flow of diesel fuel injector nozzles: A review. Int. J. Engine Res. 2001, 2, 1-22. [CrossRef]

113. Wei, H.; Chen, X.; Wang, G.; Zhou, L.; An, S.; Shu, G. Effect of swirl flow on spray and combustion characteristics with heavy fuel oil under two-stroke marine engine relevant conditions. Appl. Therm. Eng. 2017, 124, 302-314. [CrossRef]

114. Yao, C.; Geng, P.; Yin, Z.; Hu, J.; Chen, D.; Ju, Y. Impacts of nozzle geometry on spray combustion of high pressure common rail injectors in a constant volume combustion chamber. Fuel 2016, 179, 235-245. [CrossRef]

115. Kumar, M.V.; Babu, A.V.; Kumar, P.R. Experimental investigation on the effects of diesel and mahua biodiesel blended fuel in direct injection diesel engine modified by nozzle orifice diameters. Renew. Energy 2018, 119, 388-399. [CrossRef]

116. Shivashimpi, M.; Alur, S.; Topannavar, S.; Dodamani, B. Combined effect of combustion chamber shapes and nozzle geometry on the performance and emission characteristics of C.I. engine operated on Pongamia. Energy 2018, 154, 17-26. [CrossRef]

117. Yaliwal, V.; Banapurmath, N.; Gireesh, N.; Hosmath, R.; Donateo, T.; Tewari, P. Effect of nozzle and combustion chamber geometry on the performance of a diesel engine operated on dual fuel mode using renewable fuels. Renew. Energy 2016, 93, 483-501. [CrossRef]

118. Sayin, C.; Gumus, M.; Canakci, M. Influence of injector hole number on the performance and emissions of a DI diesel engine fueled with biodiesel-diesel fuel blends. Appl. Therm. Eng. 2013, 61, 121-128. [CrossRef]

119. Park, S.H.; Yoon, S.H.; Lee, C.S. Effects of multiple-injection strategies on overall spray behavior, combustion, and emissions reduction characteristics of biodiesel fuel. Appl. Energy 2011, 88, 88-98. [CrossRef] 
120. Tumbal, A.V.; Banapurmath, N.; Tewari, P.G. Effect of injection timing, injector opening pressure, injector nozzle geometry, and swirl on the performance of a direct injection, compression-ignition engine fuelled with honge oil methyl ester (HOME). Int. J. Automot. Technol. 2016, 17, 35-50. [CrossRef]

121. Vairamuthu, G.; Sundarapandian, S.; Kailasanathan, C.; Thangagiri, B. Experimental investigation on the effects of cerium oxide nanoparticle on Calophyllum inophyllum (Punnai) biodiesel blended with diesel fuel in DI diesel engine modified by nozzle geometry. J. Energy Inst. 2016, 89, 668-682. [CrossRef]

122. Lahane, S.; Subramanian, K. Impact of nozzle holes configuration on fuel spray, wall impingement and NOx emission of a diesel engine for biodiesel-diesel blend (B20). Appl. Therm. Eng. 2014, 64, 307-314. [CrossRef]

123. Vasileva, T.K.; Kamburov, A.D.; Vasileva, V.D. Blended Learning in Autotronic system. In Proceedings of the ELECTRONICS'2005, Sozopol, Bulgaria, 21-23 September 2005; Volume 2, pp. 97-102.

124. Khandal, S.; Banapurmath, N.; Gaitonde, V.N.; Hiremath, S. Paradigm shift from mechanical direct injection diesel engines to advanced injection strategies of diesel homogeneous charge compression ignition (HCCI) engines-A comprehensive review. Renew. Sustain. Energy Rev. 2017, 70, 369-384. [CrossRef]

125. Park, S.; Kim, H.J.; Shin, D.H.; Lee, J.-T. Effects of various split injection strategies on combustion and emissions characteristics in a single-cylinder diesel engine. Appl. Therm. Eng. 2018, 140, 422-431. [CrossRef]

126. Badami, M.; Mallamo, F.; Millo, F.; Rossi, E.E. Influence of Multiple Injection Strategies on Emissions, Combustion Noise and BSFC of a DI Common Rail Diesel Engine. SAE Tech. Pap. Ser. 2002, 111, 1118-1129.

127. Sindhu, R.; Rao, G.A.P.; Murthy, K.M. Effective reduction of NOx emissions from diesel engine using split injections. Alex. Eng. J. 2018, 57, 1379-1392. [CrossRef]

128. Li, X.; Zhou, H.; Zhao, L.M.; Su, L.; Xu, H.; Liu, F. Effect of split injections coupled with swirl on combustion performance in DI diesel engines. Energy Convers. Manag. 2016, 129, 180-188. [CrossRef]

129. Sun, Y.; Yu, X.; Dong, W.; Chen, H.; Hu, Y. Effect of split injection on particle number (PN) emissions in GDI engine at fast-idle through integrated analysis of optics and mechanics. Energy 2018, 165, 55-67. [CrossRef]

130. Yang, B.; Zeng, K. Effects of natural gas injection timing and split pilot fuel injection strategy on the combustion performance and emissions in a dual-fuel engine fueled with diesel and natural gas. Energy Convers. Manag. 2018, 168, 162-169. [CrossRef]

131. Jeon, J.; Park, S. Effects of pilot injection strategies on the flame temperature and soot distributions in an optical CI engine fueled with biodiesel and conventional diesel. Appl. Energy 2015, 160, 581-591. [CrossRef]

132. Dhar, A.; Agarwal, A.K. Experimental investigations of the effect of pilot injection on performance, emissions and combustion characteristics of Karanja biodiesel fuelled CRDI engine. Energy Convers. Manag. 2015, 93, 357-366. [CrossRef]

133. Qi, D.; Leick, M.; Liu, Y.; Lee, C.-F.F. Effect of EGR and injection timing on combustion and emission characteristics of split injection strategy DI-diesel engine fueled with biodiesel. Fuel 2011, 90, 1884-1891. [CrossRef]

134. Plamondon, E.; Seers, P. Parametric study of pilot-main injection strategies on the performance of a light-duty diesel engine fueled with diesel or a WCO biodiesel-diesel blend. Fuel 2019, 236, 1273-1281. [CrossRef]

135. How, H.; Masjuki, H.H.; Kalam, M.; Teoh, Y. Influence of injection timing and split injection strategies on performance, emissions, and combustion characteristics of diesel engine fueled with biodiesel blended fuels. Fuel 2018, 213, 106-114. [CrossRef]

136. Le, T.; Masjuki, H.H.; How, H.; Kalam, M.; Yu, K.H.; Alabdulkarem, A. Effect of two-stage injection dwell angle on engine combustion and performance characteristics of a common-rail diesel engine fueled with coconut oil methyl esters-diesel fuel blends. Fuel 2018, 234, 227-237.

137. Baumgarten, C. Mixture Formation in Internal Combustion Engines; Springer Science \& Business Media: New York, NY, USA, 2006.

138. Pierpont, D.A.; Reitz, R.D. Effects of Injection Pressure and Nozzle Geometry on D.I. Diesel Emissions and Performance. SAE Tech. Pap. Ser. 1995, 104, 1041-1050.

139. Mahr, B. Future and Potential of Diesel Injection Systems, in Thermo-and Fluid Dynamic Processes in Diesel Engines 2; Springer: Berlin/Heidelberg, Germany, 2004; pp. 3-17.

140. Mulemane, A.; Han, J.-S.; Lu, P.-H.; Yoon, S.-J.; Lai, M.-C. Modeling Dynamic Behavior of Diesel Fuel Injection Systems. SAE Tech. Pap. Ser. 2004. [CrossRef]

141. Bianchi, G.M.; Falfari, S.; Brusiani, F.; Pelloni, P.; Osbat, G.; Parotto, M. Numerical Investigation of Critical Issues in Multiple-Injection Strategy Operated by a New C.R. Fast-Actuation Solenoid Injector. SAE Tech. Pap. Ser. 2005. [CrossRef] 
142. Beierer, P.; Huhtala, K.; Lehto, E.; Vilenius, M. Study of the Impact of System Characteristics on Pressure Oscillations in a Common Rail Diesel Fuel Injection System. SAE Tech. Pap. Ser. 2005. [CrossRef]

143. Payri, R.; Salvador, F.; Gimeno, J.; De La Morena, J.; Rubio, F.J.S. Influence of injector technology on injection and combustion development-Part 1: Hydraulic characterization. Appl. Energy 2011, 88, 1068-1074. [CrossRef]

144. Yu, W.; Yang, W.; Mohan, B.; Tay, K.L.; Zhao, F. Macroscopic spray characteristics of wide distillation fuel (WDF). Appl. Energy 2017, 185, 1372-1382. [CrossRef]

145. Payri, R.; Salvador, F.; Gimeno, J.; De La Morena, J.; Rubio, F.J.S. Influence of injector technology on injection and combustion development-Part 2: Combustion analysis. Appl. Energy 2011, 88, 1130-1139. [CrossRef]

146. Jo, I.S.; Chung, M.C.; Kim, S.M.; Sung, G.S.; Lee, J.W. Experimental investigation and hydraulic simulation of dynamic effects on diesel injection characteristics in indirect acting piezo-driven injector with bypass-circuit system. Int. J. Automot. Technol. 2015, 16, 173-182. [CrossRef]

147. Chung, M.; Kim, J.; Kim, S.; Sung, G.; Lee, J. Effects of hydraulic flow and spray characteristics on diesel combustion in CR direct-injection engine with indirect acting Piezo injector. J. Mech. Sci. Technol. 2015, 29, 2517-2528. [CrossRef]

148. D'Ambrosio, S.; Ferrari, A. Diesel engines equipped with piezoelectric and solenoid injectors: Hydraulic performance of the injectors and comparison of the emissions, noise and fuel consumption. Appl. Energy 2018, 211, 1324-1342.

149. Salvador, F.; Gimeno, J.; De La Morena, J.; Carreres, M.; Rubio, F.J.S. Using one-dimensional modeling to analyze the influence of the use of biodiesels on the dynamic behavior of solenoid-operated injectors in common rail systems: Results of the simulations and discussion. Energy Convers. Manag. 2012, 54, 122-132. [CrossRef]

150. Payri, R.; Salvador, F.; Martí-Aldaraví, P.; Martínez-López, J.; Rubio, F.J.S. Using one-dimensional modeling to analyse the influence of the use of biodiesels on the dynamic behavior of solenoid-operated injectors in common rail systems: Detailed injection system model. Energy Convers. Manag. 2012, 54, 90-99. [CrossRef]

151. Park, S.W. Optimization of combustion chamber geometry for stoichiometric diesel combustion using a micro genetic algorithm. Fuel Process. Technol. 2010, 91, 1742-1752. [CrossRef]

152. Lee, S.; Park, S. Optimization of the piston bowl geometry and the operating conditions of a gasoline-diesel dual-fuel engine based on a compression ignition engine. Energy 2017, 121, 433-448. [CrossRef]

153. Kakaee, A.-H.; Nasiri-Toosi, A.; Partovi, B.; Paykani, A. Effects of piston bowl geometry on combustion and emissions characteristics of a natural gas/diesel RCCI engine. Appl. Therm. Eng. 2016, 102, 1462-1472. [CrossRef]

154. Gafoor, C.A.; Gupta, R. Numerical investigation of piston bowl geometry and swirl ratio on emission from diesel engines. Energy Convers. Manag. 2015, 101, 541-551. [CrossRef]

155. Khan, S.; Panua, R.; Bose, P.K. Combined effects of piston bowl geometry and spray pattern on mixing, combustion and emissions of a diesel engine: A numerical approach. Fuel 2018, 225, 203-217. [CrossRef]

156. Channappagoudra, M.; Ramesh, K.; Manavendra, G.; Manavendra, G. Comparative study of standard engine and modified engine with different piston bowl geometries operated with B20 fuel blend. Renew. Energy 2019, 133, 216-232. [CrossRef]

157. Galloni, E.; Fontana, G.; Palmaccio, R. Effects of exhaust gas recycle in a downsized gasoline engine. Appl. Energy 2013, 105, 99-107. [CrossRef]

158. Ayodhya, A.S.; Lamani, V.T.; Bedar, P.; Kumar, G.N. Effect of exhaust gas recirculation on a CRDI engine fueled with waste plastic oil blend. Fuel 2018, 227, 394-400. [CrossRef]

159. Rahman, M.A.; Ruhul, A.; Aziz, M.; Ahmed, R. Experimental exploration of hydrogen enrichment in a dual fuel CI engine with exhaust gas recirculation. Int. J. Hydrog. Energy 2017, 42, 5400-5409. [CrossRef]

160. Millo, F.; Giacominetto, P.F.; Bernardi, M.G. Analysis of different exhaust gas recirculation architectures for passenger car Diesel engines. Appl. Energy 2012, 98, 79-91. [CrossRef]

161. Wang, H.; Zheng, Z.; Yao, M.; Reitz, R.D. An Experimental and Numerical Study on the Effects of Fuel Properties on the Combustion and Emissions of Low-Temperature Combustion Diesel Engines. Combust. Sci. Technol. 2014, 186, 1795-1815. [CrossRef]

162. Lee, H.; Park, Y.; Sunwoo, M. Observer design for exhaust gas recirculation rate estimation in a variable-geometry turbocharger diesel engine using a model reference identification scheme. Proc. Inst. Mech. Eng. Part D J. Automob. Eng. 2014, 228, 1688-1699. [CrossRef] 
163. Wang, B.; Wang, Z.; Shuai, S.; Yang, H.; Wang, J. Combustion and emission characteristics of Multiple Premixed Compression Ignition (MPCI) fuelled with naphtha and gasoline in wide load range. Energy Convers. Manag. 2014, 88, 79-87. [CrossRef]

164. Li, W.; Liu, Z.; Wang, Z. Experimental and theoretical analysis of the combustion process at low loads of a diesel natural gas dual-fuel engine. Energy 2016, 94, 728-741. [CrossRef]

165. Rakopoulos, C.D.; Rakopoulos, D.C.; Mavropoulos, G.C.; Kosmadakis, G. Investigating the EGR rate and temperature impact on diesel engine combustion and emissions under various injection timings and loads by comprehensive two-zone modeling. Energy 2018, 157, 990-1014. [CrossRef]

166. Yasin, M.H.M.; Mamat, R.; Yusop, A.F.; Idris, D.M.N.D.; Yusaf, T.; Rasul, M.; Najafi, G. Study of a Diesel Engine Performance with Exhaust Gas Recirculation (EGR) System Fuelled with Palm Biodiesel. Energy Procedia 2017, 110, 26-31. [CrossRef]

167. Shi, X.; Liu, B.; Zhang, C.; Hu, J.; Zeng, Q. A study on combined effect of high EGR rate and biodiesel on combustion and emission performance of a diesel engine. Appl. Therm. Eng. 2017, 125, 1272-1279. [CrossRef]

168. Can, Ö.; Öztürk, E.; Solmaz, H.; Aksoy, F.; Çinar, C.; Yücesu, H.S. Combined effects of soybean biodiesel fuel addition and EGR application on the combustion and exhaust emissions in a diesel engine. Appl. Therm. Eng. 2016, 95, 115-124. [CrossRef]

169. Sakhare, N.M.; Shelke, P.S.; Lahane, S. Experimental Investigation of Effect of Exhaust Gas Recirculation and Cottonseed B20 Biodiesel Fuel on Diesel Engine. Procedia Technol. 2016, 25, 869-876. [CrossRef]

170. Mahla, S.K.; Dhir, A.; Gill, K.J.; Cho, H.M.; Lim, H.-C.; Chauhan, B.S.; Hee, C.L. Influence of EGR on the simultaneous reduction of NOx-smoke emissions trade-off under CNG-biodiesel dual fuel engine. Energy 2018, 152, 303-312. [CrossRef]

171. Chaichan, M.T. Performance and emission characteristics of CIE using hydrogen, biodiesel, and massive EGR. Int. J. Hydrog. Energy 2018, 43, 5415-5435. [CrossRef]

172. Praveen, A.; Rao, G.L.N.; Balakrishna, B. Performance and emission characteristics of a diesel engine using Calophyllum Inophyllum biodiesel blends with TiO2 nanoadditives and EGR. Egypt. J. Pet. 2018, 27, 731-738. [CrossRef]

173. Solaimuthu, C.; Ganesan, V.; Senthilkumar, D.; Ramasamy, K. Emission reductions studies of a biodiesel engine using EGR and SCR for agriculture operations in developing countries. Appl. Energy 2015, 138, 91-98. [CrossRef]

174. Arfaoui, J.; Boudali, L.K.; Ghorbel, A.; Delahay, G. Effect of vanadium on the behaviour of unsulfated and sulfated Ti-pillared clay catalysts in the SCR of NO by NH3. Catal. Today 2009, 142, 234-238. [CrossRef]

(C) 2020 by the author. Licensee MDPI, Basel, Switzerland. This article is an open access article distributed under the terms and conditions of the Creative Commons Attribution (CC BY) license (http://creativecommons.org/licenses/by/4.0/). 